\title{
Mass extinction and recovery of the Early Toarcian (Early Jurassic) brachiopods linked to climate change in Northern and Central Spain
}

\author{
Fernando García Joral $^{\mathrm{a}}$ *, Juan J. Gómez ${ }^{\mathrm{b}}$, Antonio Goy ${ }^{\mathrm{a}}$ \\ ${ }^{a}$ Dpto. de Paleontología, Facultad de Ciencias Geológicas (UCM) and Instituto de Geología Económica (CSIC-UCM), 28040 Madrid, Spain

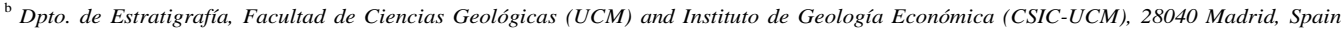

\begin{abstract}
The Early Toarcian mass extinction event represented the most important Mesozoic and Cenozoic turnover of the population of brachiopods and severely affected other benthic fauna. Two main hypotheses have been proposed to explain the synchronous and global mass extinction: an oceanic anoxic event or a warming episode. To test both hypotheses, the dynamics of the brachiopod assemblages below and above the extinction boundary are analyzed and compared with the seawater paleotemperature variations, calculated from the $\delta^{18} \mathrm{O}$ data recorded in belemnite rostra. Five sections from Northern and Central Spain, well dated with ammonites, have been selected for this study. The sections show no indication of sedimentary breaks and contain abundant brachiopods, which have been grouped into four assemblages. The changes observed in the brachiopod assemblages show a close correlation with the changes in the seawater paleotemperatures. The oldest assem- blage (assemblage 1) coincides with a cooling interval recorded to have taken place in the latest Pliensbachian. Paleobiogeographical reconstruction shows that this assemblage was distributed at paleolatitudes between 30 and $45^{\circ} \mathrm{N}$, with a preference for relatively cool waters. With the rise of temperatures that took place during the earliest Toarcian Tenuicostatum Zone, assemblage 1 was substituted by assemblage 2, which composed of different species of the same genera but considerably restricted to the warmer waters of lower paleolatitudes, between 28 and $35^{\circ} \mathrm{N}$. Coinciding with the rapid and pronounced increase in seawater temperature, recorded at the Tenuicostatum-Serpentinum zonal boundary, all of these brachiopod species disappeared in the studied localities, marking clearly the extinction boundary. Predominant southward currents through the Laurasian Seaway precluded the possible migration of the brachiopods to cooler northern waters. The brachiopods' disappearance is independent from the oxygenation degree of the sea bottom, and therefore the rapid warming seems to be the most plausible cause of the mass extinction. After the extinction event, the recovery of the brachiopods was uneven. Subsequent to a brief pause, recovery was rapid in Central Spain and in other southern areas of Western Tethys, whereas in northern Spain and in the whole of Europe north of the French Central Massif, brachiopods did not recover until the Mid to Late Toarcian times.
\end{abstract}

Keywords: Brachiopods Mass extinction Paleoclimate Stable isotopes Early Toarcian

\section{Introduction}

One of the most important mass extinctions of the Mesozoic was recorded around the Tenuicostatum-Serpentinum zonal boundary (182.7 Ma, Ogg, 2004) of the Lower Toarcian (Lower Jurassic). This extinction event specially affected the benthic organisms, but nektonic groups also suffered significant crises (e.g. Hallam, 1986, 1987; Arias et al., 1992; Little and Benton, 1995; Aberhan and Fürsich, 1997; Harries and Little, 1999; García Joral and Goy, 2000; Pálfy and Smith, 2000; Vörös, 2002; Cecca and Macchioni, 2004; Zakharov et al., 2006; Gómez et al., 2008; Nikitenko, 2008; Gómez and Arias, 2010; Gómez and Goy, 2010).

\footnotetext{
* Correspondingauthor.Tel.: +34913944853; fax:+34913944849.

E-mail addresses: fgjoral@geo.ucm.es (F. García Joral), jgomez@geo.ucm.es (J.J. Gómez), angoy@geo.ucm.es (A. Goy).
}

Two different hypotheses have been proposed to explain this episode of massive loss of biodiversity. One hypothesis assumes that the main cause of the mass extinction is the global generalization of anoxic environments (e.g. Jenkyns, 1988; Bassoullet and Baudin, 1994; Nikitenko and Shurygin, 1994; Harries and Little, 1999; Pálfy and Smith, 2000; Jenkyns et al., 2002; Vörös, 2002; Aberhan and Baumiller, 2003;

Mattioli et al., 2004, 2009; Tremolada et al., 2005; Wignall et al., 2005; Mailliot et al., 2008). This opinion is inferred from the deposition of organic-rich black-shale facies during Early Toarcian, as the result of a supposedly synchronous and global major Early Toarcian Oceanic Anoxic Event (ETOAE) (Jenkyns, 1985, 1988, 1999, 2003; Jenkyns and

Clayton, 1986, 1997; Jenkyns et al., 1994, 2001, 2002; Jiménez et al., 1996; Mailliot et al., 2006). However, reappraisal of this hypothesis through highresolution stratigraphy indicates that the ETOAE seems to be diachronous at the ammonite zone/subzone scale and only occasionally coincident with the mass extinction boundary (Wignall et al., 2005; Gómez et al., 2008; McArthur et al., 2008), and that 
deposition of significant black-shale facies, containing above 5 wt.\% of total organic carbon (TOC), is restricted to some areas such as the Central European basin.

The other hypothesis links the mass extinction event to the out- standing Early Toarcian warming interval, which has been docu- mented in many different areas of Western Europe such as the UK (Jenkyns et al., 1991; Sælen et al., 1996; McArthur et al., 2000; Jenkyns, 2003), Germany (Röhl et al., 2001; Schmid-Röhl et al., 2002), Spain (Rosales et al., 2003, 2004; Gómez et al., 2008; Gómez and Arias, 2010; Gómez and Goy, 2010), France (Dera et al., 2009), Bulgaria (Metodiev and Koleva-Rekalova, 2008), and that has also been recorded in North Siberia and in the Arctic (Zakharov et al., 2006). Synchronism between the mass extinction event and the recorded climate change supports that warming was the main cause of marine faunal extinction (Gómez et al., 2008; Gómez and Arias, 2010; Gómez and Goy, 2010). Among the benthic organisms, brachiopods are one of the groups that were more affected by this mass extinction, representing the most important turnover event recorded in this group during the Mesozoic and the Cenozoic eras (García Joral et al., 2000; Gahr, 2002; Vörös, 2002; Comas-Rengifo et al., 2006).

The variations in the brachiopod assemblages below and above the extinction boundary in two sections located in northern Spain (Asturias and the Basque-Cantabrian Basin) and in three sections located in central Spain (Iberian Range) are described (Fig. 1). In all the studied sections, the Lower Toarcian stratigraphical record is virtually continuous, with no significant sedimentary breaks; the brachiopods are abundant, represented by well known taxa from a systematic point of view, and quite similar from one locality to another.

The aim of this work is to show the changes in the diversity and taxonomical composition of the brachiopod assemblages before, during and after the extinction event and to compare the recorded changes with the synchronous climate change manifested in the seawater increment in temperature, inferred from the $\delta^{18} \mathrm{O}$ values obtained from diagenetically screened calcite of belemnite rostra.

\section{Materials and methods}

The five sections have been studied bed by bed and those levels close to the extinction boundary were sampled more exhaustively to have a high resolution record of the present/absent taxa. Belemnites were prepared for isotopic studies in three of the studied sections. A total of 54 belemnite rostra were collected in the West Rodiles section, and 72 analyses of stable isotope were performed; 19 belem- nites were collected and analyzed at the San Andres section and 50 belemnites were collected and analyzed at La Almunia section.

Belemnite rostra were selected to obtain the primary stable isotope signal of the Early Toarcian seawater. In order to test for any possible burial diagenetic alteration of the collected belemnites, the rostra were studied through polished samples and thick sections under the petrographic and the cathodoluminescence microscope. Only the potentially unaltered nonluminescent portions of the rostra were sampled using a microscope-mounted dental drill. Samples with insufficient space for sampling were rejected.

To be sure that only calcite was present in the samples, X-ray diffraction techniques were used in 30 belemnite samples. The stable isotope analyses were performed in the Michigan University (USA) and the Salamanca University (Spain) labs. Several samples were analyzed in both laboratories with acceptable repeatability. Isotope ratios are reported in per mil respect to the standard Peedee belem- nite (PDB) in all samples. Analytical error was in most cases better than $\pm 0.1 \%$ on both carbon and oxygen.

For the calculation of the Toarcian seawater temperatures recorded in the belemnite rostra, the Anderson and Arthur (1983) equation: $\mathrm{T}\left({ }^{\circ} \mathrm{C}\right)=$ $16.0-4.14\left(\delta_{\mathrm{c}}-\delta_{\mathrm{w}}\right)+0.13\left(\delta_{\mathrm{c}}-\delta_{\mathrm{w}}\right)^{2}$ has been

used. Inthisequation $\delta_{\mathrm{c}}=\delta^{18}$ OPDBis thecomposition of the sample, and $\delta_{\mathrm{w}}=\delta^{18} \mathrm{OSMOW}$ is the composition of ambient seawater. Normal values of marine salinity $\mathrm{S}=34.3 \%$ (Wright, 1987) and $\delta_{\mathrm{w}}$ values of

$-1 \%$ for a non-glacial ocean water were used. To use the belemnite rostra as a proxy for paleotemperature calculation, it has been assumed that 1) the sampled non-luminescent biogenic calcite of the belemnite rostra collected in the Toarcian deposits of the three studied sections precipitated in equilibrium with the seawater,

2) biogenic calcite retains the primary isotopic composition of the seawater, and 3) sampling bias, vital effects, skeletal growth and belemnites migration are not mainly responsible for the obtained variations in the $\delta^{18} \mathrm{O}$ values, and consequently that the obtained curve virtually only reflects changes in environmental parameters (Sælen et al., 1996; Rexfort and Mutterlose, 2009).

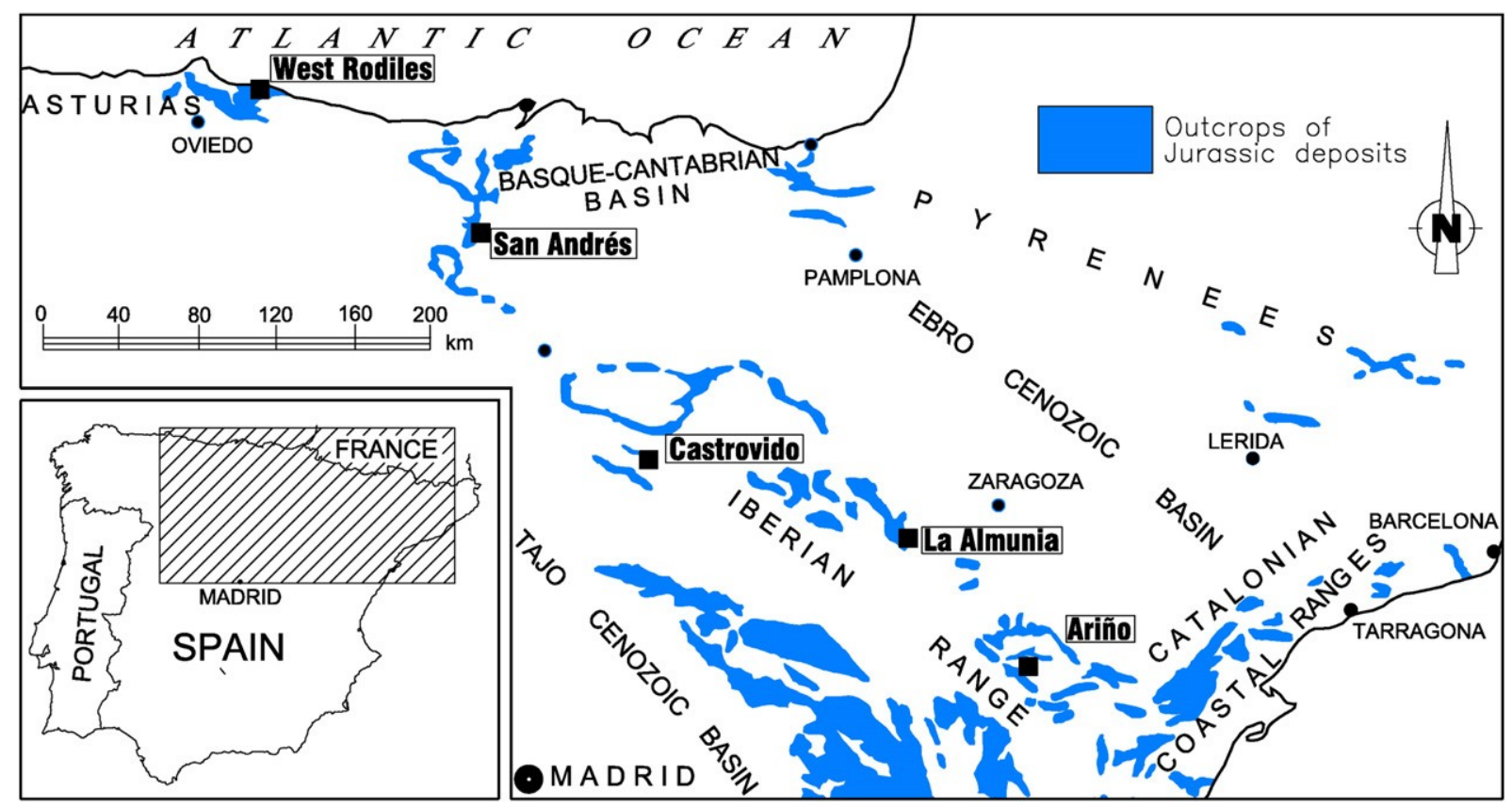

Fig. 1. Map showing the location of the studied sections. The study area constitutes a northeast-southwest transverse from the West Rodiles section in Asturias through the San Andrés section in the Basque-Cantabrian Basin and the Castrovido, La Almunia and Ariño sections in the Iberian Range. 


\section{Stratigraphic sections}

All the studied sections are expanded, with irrelevant or no in- dication of condensation or sedimentary discontinuities. From north to south, in the West Rodiles section at Asturias (Fig. 2), the Lower Toarcian deposits are composed of an alternation of limestone and marl corresponding to the Santa Mera Member of the Rodiles Formation (Valenzuela et al., 1986; García-Ramos et al., 1992), in which a thinly banded interval containing up to 3.2 wt.\% TOC, marks the Tenuicostatum-Serpentinum zonal boundary. At the San Andres section (Fig. 2), located in the Basque-Cantabrian Basin, the Lower Toarcian deposits are represented by an alternation of limestone and marl corresponding to the Castillo Pedroso Formation (Quesada et al., 2005), with interbedded organic horizons (up to $1.5 \mathrm{wt} . \%$ TOC) below and above the Tenuicostatum-Serpentinum zonal boundary. In the Iberian Range sections (Figs. 2 and 3), the Lower Toarcian sediments are represented by an alternation of lime mudstone and marl corresponding to the Turmiel Formation (Goy et al., 1976; Gómez et al., 2003). No organicrich facies were found and only one value above $1 \mathrm{wt} \%$ TOC (1.2 wt.\%), corresponding to the lower part of the Tenuicostatum Zone, was obtained from a single sample at La Almunia section. Chronostratigraphy obtained in the different areas has been adapted to the standard ammonite zones and subzones proposed by Dommergues et al. (1997), Elmi et al. (1997) and Page (2003).

\section{Brachiopod assemblages}

Significant differences in the brachiopod diversity have been observed among the sections located in northern Spain and the sections located in the Iberian Range of central Spain. The number of species represented in the northern Spain sections is significantly lower than the diversity found in the central Spain sections, probably reflecting different environmental conditions between both areas. In most cases shells are not recrystallized, and no significant differences in shell preservation are observed.

The twenty-two recognized species of brachiopods have been grouped into four assemblages, and their respective stratigraphical distribution has been represented in Figs. 2 and 3. These Lower Toarcian brachiopod assemblages, previously described by Goy et al. (1997) and García Joral and Goy (2000), are illustrated in Figs. 4 and 5.

Assemblage 1 is constituted of typical Pliensbachian taxa, which extend their stratigraphical distributions up to the lower part of the Tenuicostatum Zone of the Lower Toarcian. Assemblage 2 is mostly confined to the Tenuicostatum Zone, though some of its components can have their first appearance at the uppermost Spinatum Zone of the Upper Pliensbachian. The species included in assemblages 1 and 2 disappear around the TenuicostatumSerpentinum zonal boundary. Only locally some species of assemblage 2 can appear in the first bed of the Serpentinum Zone, but the possibility of local reworking with incorporation of some fossils from previous beds into the basal beds of the Serpentinum Zone cannot be dismissed. Consequently, the boundary between the Tenuicostatum and the Serpentinum zones marks the extinction boundary in all the studied sections, as in many other sections of Europe, Northern Africa and probably in North Siberia and the Arctic Region. Below this boundary, the uppermost Pliensbachian Spinatum Zone and the lowermost Toarcian Tenuicos- tatum Zone represent the extinction interval in the sense of Kauffman and Erwin (1995). Comparison of the age of this interval with other European sections indicates its synchronism (Hallam, 1987; Arias et al., 1992; Little and Benton, 1995; Aberhan and Fürsich, 1997; Goy et al., 1998; Harries and Little, 1999; García Joral and Goy;, 2000; Pálfy and Smith, 2000; Cecca and Macchioni, 2004; Zakharov et al., 2006; Gómez et al., 2008; Nikitenko, 2008; Gómez and Arias, 2010; Gómez and Goy, 2010). Assemblage 3 is constituted of just one species, Soaresirhynchia bouchardi, which first appears in the lower part of the
Serpentinum Zone, just above the extinction boundary. Assemblage 4 appears at the Serpentinum Zone, starting in the last horizons con- taining $S$. bouchardi, and extends up to the Middle Toarcian Bifrons Zone. It is dominated by species of the genera Homoeorhynchia and Telothyris. Assemblages 3 and 4 clearly represent the repopula- tion interval, but this recovery is only recorded at the Lower Toarcian in the Iberian Range sections. These assemblages do not appear in the northern Spain sections, where no brachiopods are recorded below the Middle Toarcian. A similar delay in the recovery of the brachiopods after the extinction is observed in other regions of western Tethys (Fig. 6), so that assemblages 3 and 4 are present in warm areas from the Serpentinum Zone, whereas in many areas of Western Europe located north of the Massif Central in France, the recovery does not start until the Middle or Upper Toarcian (Ager, 1978; Tchoumatchenco, 1984; Georgescu, 1990; García Joral and Goy, 2009). Only occasional records of Pseudogibbirhynchia jurensis (Alméras et al., 1997) and Neozeilleria lycetti (Delance, 1974) have been cited in the Middle Toarcian Bifrons or Variabilis zones.

\section{Paleogeography and paleobiogeographical distribution of the brachiopod assemblages}

\subsection{Paleogeographical setting}

During the Late Pliensbachian-Early Toarcian, central Iberia was located at a latitude of about $30-35^{\circ} \mathrm{N}$ (Osete et al., 2000, 2010), constituting a system of platforms that were distributed around the Iberian Massif. This platform system was connected eastward with the Neotethys Ocean, to the north with the Arctic, through the so-called "Viking Straits" (Poulton and Callomon, 1977; Callomon, 1979) or "Laurasian Seaway" (Bjerrum et al., 2001), and to the West with South America through the Hispanic Corridor, probably intermittently open since the Sinemurian/Pliensbachian (Smith, 1983; Damborenea, 2000; Aberhan, 2001; Sha, 2002) (Fig. 6a and b). Modeling of the paleoceanographical conditions through the Laurasian Seaway indi- cate the presence of predominant southward currents along this passage (Bjerrum et al., 2001), which has also been supported by the distribution of the ostracods at that time (Arias, 2006, 2007), by the Koninckinid brachiopods (Vörös, 2002) and by the neodymium isotopes (Dera et al., 2009).

In regions of Western Europe located north of the Iberian Massif, an euxinic basin, mostly due to the stagnation of stratified water masses, gave rise to the deposition of well developed black-shale facies where values higher than 5 wt.\% TOC are common (Sælen et al., 2000; Röhl et al., 2001; van Breuguel et al., 2006; McArthur, et al., 2008). To the south of this area, scattered intervals commonly containing below 5 wt.\% TOC, have been found in many other places (e.g. Southern France, Spain, Portugal, Italy, and Northern Morocco). In Argentina, only two samples having TOC values slightly above 5 wt.

$\%$ TOC have been reported from the boundary beds between the Tenuicostatum and Hoelderi Zones in the Neuquén Basin (Al-Suwaidi et al., 2010), indicating the presence of local, ephemeral and/or diachronous restriction conditions. For the Early Toarcian euxinic sea of NW Europe, the term regional anoxic event, (RAE) has been proposed by McArthur et al. (2008) to substitute the concept of oceanic anoxic event (OAE) proposed by Jenkyns (1988).

\subsection{Paleobiogeographical distribution of the brachiopod assemblages}

Plotting the distribution of the brachiopod assemblages referred to in this paper on the paleogeographical map of Europe and northern Africa (Fig. 6) shows that these assemblages are present in a wide area.

Assemblage 1 shows a clear relationship with the taxa found in other neighboring platforms such as in the UK, Germany, France, Portugal and northern Africa, the so-called "European" province (cf. 

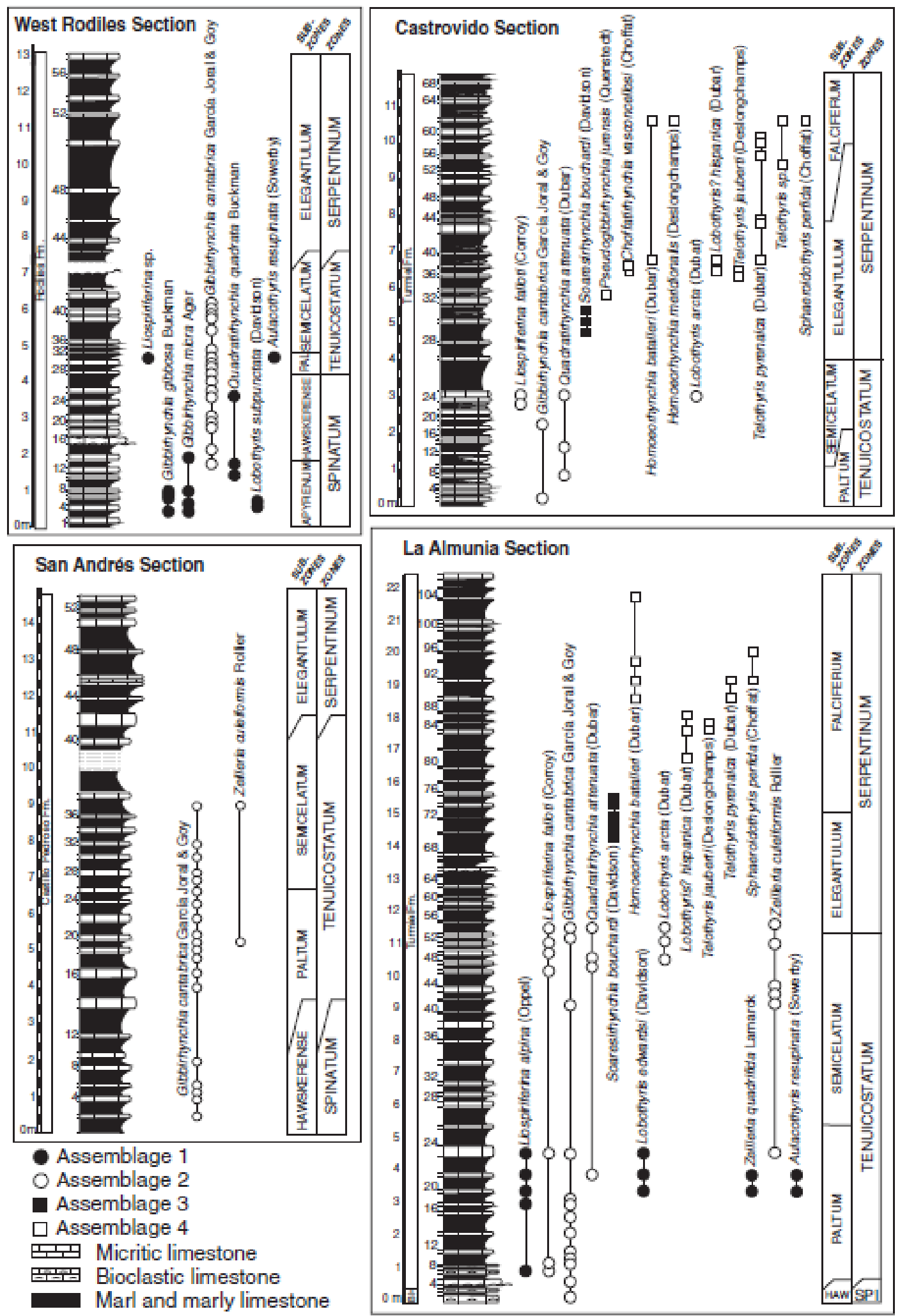

Hg. 2 Distribution of the species and assemblages of brachiopods in the West Rodiles, Sun Andres, Castrovido and La Almumia sections. Ammonites-based biochronostraigraphy in

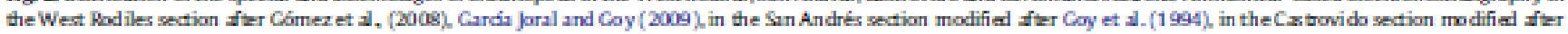
Coma-Rengifo et al (1988), and in the la Almuniz section after Cory and Martíner (1990), Coy et al. (1996), Cómez et al (2008), 


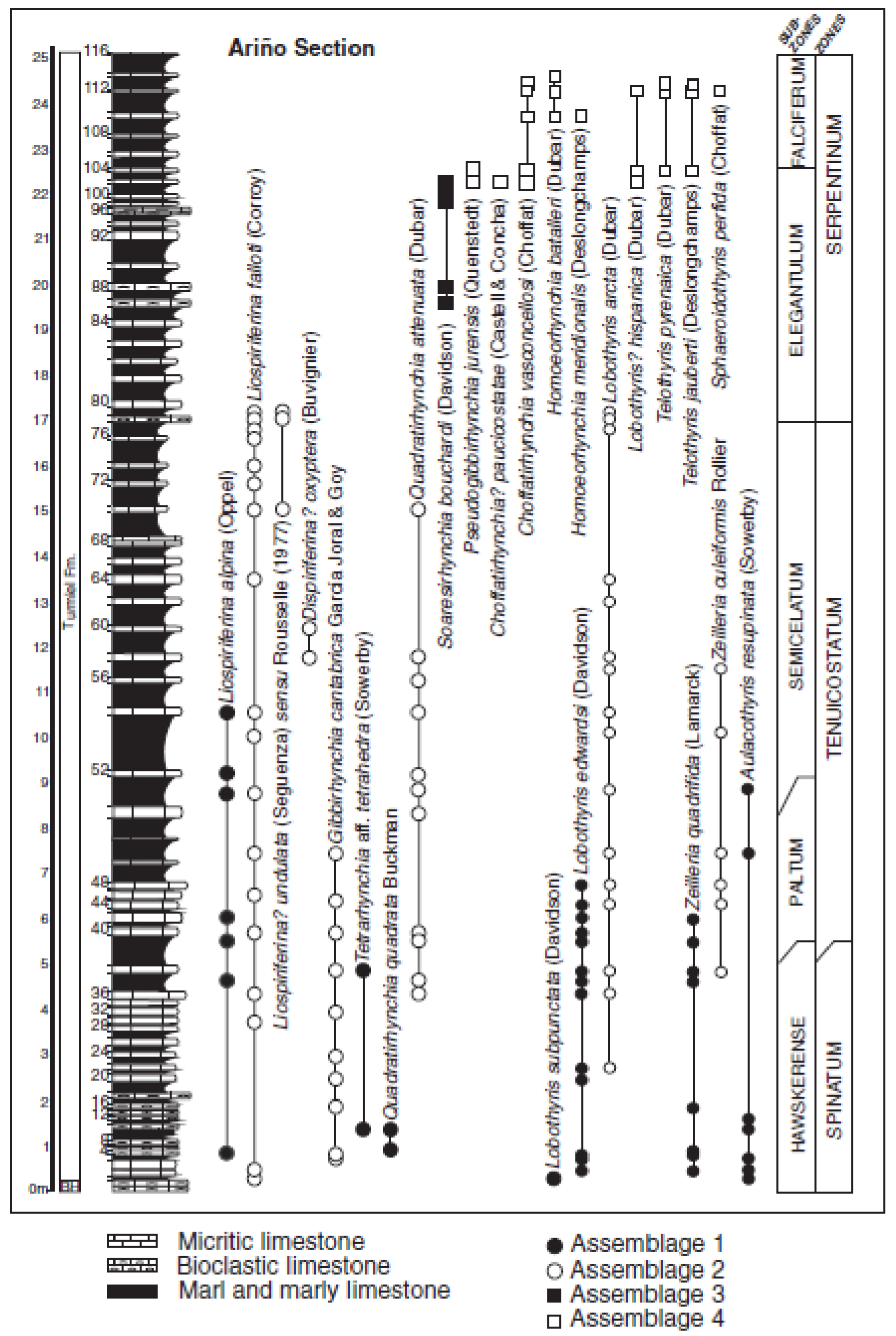

Fig. 3. Dis tribution of the spedes and assenblages of brachiopods in the Arinio section.

Ammonites based biochronostratigraphy in this section has been modified after Coy et al. (1997), Osete et al (2007).

Ager, 1967, 1971; Hallam, 1971; Vörös, 1977, 1984, 1987; Manceñido, 2002). This assemblage can clearly be distinguished from others found in warmer Tethyan areas of the "Mediterranean" Province, though it includes genera of wide distribution (Liospiriferina, Tetrurhynchia, Gibbirhynchia, Lobothyris, and Zeilleria) that can be considered as nearly cosmopolitan. This provincialism has been primarily attributed to bathymetric/bottom controlled differences (Ager, 1965;
Vörös, 2005). However, as shown in Fig. 6b, the species constituting assemblage 1 were mainly distributed at paleolatitudes between 30 and $45^{\circ} \mathrm{N}$, suggesting a latitudinal/temperature control, and therefore inhabiting relatively cool waters.

Assemblage 2 is notably more restricted to paleolatitudes around $28^{\circ}-35^{\circ} \mathrm{N}$, and following the same reasoning, preferentially linked to warmer waters. It includes species of the same genera as assemblage 1 
but of a more endemic distribution. The dominant species, Gibbirhynchia cantabrica, is characteristic of the northern Iberian platform system (Asturias, Basque-Cantabrian Basin and western Pyrenees), though this species can also been found in the central Iberian Range and to the south of the Armorican Massif(Alméras andFauré, 2000; Alméras and Becaud, 2002).

Assemblage 3, composed of the single species Soaresirhynchia bouchardi, has a relatively wide geographical distribution, from southern England to Morocco and from Portugal to the Balkans, including some typically Mediterranean areas such as the High Atlas in Morocco (Rousselle, 1978), the eastern Betic Range in southern Spain (Baeza-Carratalá, 2008), Majorca Island (Álvaro et al., 1989) or the Central Apeninnes (Graziano et al., 2006). Except for a few occurrences, S. bouchardi is distributed in paleolatitudes lower than $35^{\circ} \mathrm{N}$ (Fig. 6), indicating a probable Mediterranean provenance, linked to warm environments. Anecdotically, this species was described in southern England (Davidson, 1852) where it is uncommon and represents the northernmost locality where this taxon has been reported.

Assemblage 4, which is centered at a paleolatitude of about $35^{\circ} \mathrm{N}$ (Fig. 6), is characteristic of the so-called "Spanish Fauna" (Choffat, 1880; Dubar, 1931; Delance, 1972) or of the Spanish Bioprovince (García Joral and Goy, 1984, 2004). Besides the Iberian Range, this assemblage extends throughout the Middle Atlas in Morocco and Western Algeria (Elmi et al., 1985, 1991), Portugal (Alméras et al., 1996), Southern Spain (Eastern Subbetic) (Bizon et al., 1966; Baeza- Carratalá, 2008), Eastern Spain (Catalonian Coastal Ranges) (Dubar, 1931; Fernández-López et al., 1998), Eastern Pyrenees (Alméras and Fauré, 2000) and Southeastern France (Alméras and Moulan, 1982; Alméras, 1996; Alméras et al., 1997). Some components of this as- semblage (often congeneric, even sometimes conspecific), have been found in South America at a similar paleolatitude (Manceñido, 1990, 2002; Manceñido and Dagys, 1992), not only supporting the exis- tence of a connection between Europe and South America through the already open Hispanic Corridor (cf. Manceñido, 2002) (Fig. 6a) but also the control of temperature in the didemic distribution of this assemblage.

\section{Oxygen isotopeandpaleotemperatures}

Correlation of the $\delta^{18} \mathrm{O}_{\text {bel }}$ curves obtained in Asturias, in the BasqueCantabrian Basin and in the Iberian Range shows strong similarities among the three areas (Fig. 7). Late Pliensbachian, $\delta^{18} \mathrm{O}_{\text {bel }}$ average values are relatively high (about 0\% in Asturias). However, throughout the lowermost Toarcian Tenuicostatum Zone, $\delta^{18} \mathrm{O}_{\text {bel }}$ values progressively decreased, reaching minimal values at the Sepentinum Zone. This was the beginning of an important negative excursion that developed from the Elegantulum Subzone (Serpenti- num Zone) up to the upper Bifrons Subzone (Middle Toarcian Bifrons

Zone), in which the $\delta^{18} \mathrm{O}_{\text {bel }}$ values severely became more negative, reaching peak values of up to $-3.8 \%$ at La Almunia section.

The curve illustrating the seawater temperature variations during the Early to Middle Toarcian (Fig. 8) shows that the paleotem- peratures recorded at the latest Pliensbachian Spinatum Zone in the West Rodiles section were relatively low, averaging $11.6{ }^{\circ} \mathrm{C}$. Similar temperatures were obtained by Rosales et al. (2004) in the Basque-
Cantabrian Basin, in northern Spain, in Germany (Bailey et al., 2003), and in several localities of Central Europe (Dera et al., 2009), indicating the presence of a notable cooling interval in the latest Pliensbachian.

The beginning of the Toarcian was coincident with the transition from this cooling interval to a progressively warmer climate. During this transition, which extends up to the upper part of the Tenuicostatum Zone, the measured average paleotemperature was

$15.5^{\circ} \mathrm{C}$ in the West Rodiles section, $14.8^{\circ} \mathrm{C}$ in the San Andres section and 16.3 ${ }^{\circ} \mathrm{C}$ in the La Almunia section. This represents a firstinterval of increasing seawater temperature at the Iberian platform system in the order of $4-5{ }^{\circ} \mathrm{C}$. The progressive warming represents an important change in the environmental conditions under which brachiopods were living. It coincides with the extinction interval, marked by the progressive replacement of brachiopods of assemblage 1, more adapted to cooler conditions, by the species of assemblage 2, better adapted to warmer environments.

Close to the Tenuicostatum-Serpentinum zonal boundary, a notable increase in seawater temperature began. The onset of this rapid warming coincides with the extinction boundary, in which all the brachiopods of assemblages 1 and 2 disappeared. Average paleotemperatures of $20^{\circ} \mathrm{C}$ in the West Rodiles section, and $23{ }^{\circ} \mathrm{C}$ in the La Almunia section were attained during this rapid warming, which extended up to the upper part of the Bifrons Zone (Bifrons Subzone) (Fig. 8). This implied an increment of temperature in the order of $4.5^{\circ} \mathrm{C}$ in the West Rodiles section, and about 6.7 ${ }^{\circ} \mathrm{C}$ in the southerly La Almunia section.

Therange of seawatertemperatures reached during the Toarcian is compatible with the temperature values measured in current oceans (NOAA). Considering that the paleolatitude of Madrid, calculated for Toarcian times, was approximately $30-35^{\circ} \mathrm{N}$ (Osete et al., 2000), the inferred paleotemperatures indicate for this warming interval values $3-6{ }^{\circ} \mathrm{C}$ above the temperatures measured in to-days oceans.

\section{Discussion}

\subsection{Correlation between the distribution of the brachiopods and temperature changes}

Inferred seawater temperatures, stratigraphical distribution of the brachiopod assemblages, and the number of species in the stud- ied sections show a close correlation (Fig. 8). The progressive warm- ing during the Tenuicostatum Zone time correlates with a progressive loss of brachiopod species and the replacement of assemblage 1 by assemblage 2 . The rapid warming at the Tenuicostatum-Serpentinum zonal boundary correlates with the disappearance of all brachiopods in the studied sections. The stable high temperatures recorded in the Serpentinum and Bifrons zones correlate with the occurrence of assemblages 3 and 4 , in which a progressive increase of species is observed.

Not enough information on the influence of temperature on the brachiopods is available. However, provinciality among many Mesozoic brachiopods approximately follows latitudinal belts, indi- cating that temperature has been an important controlling factor (Middlemiss, 1984; Price, 1999). Vörös (2002) described how some species of Koninckinidae of the Upper Pliensbachian and Lower

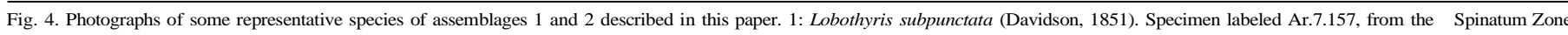

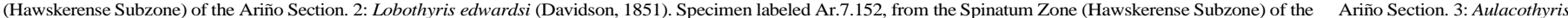

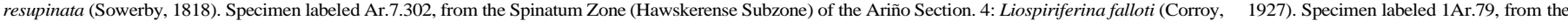

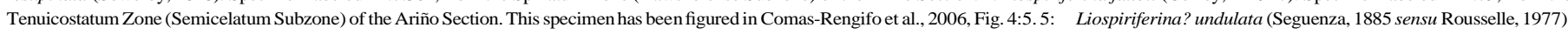

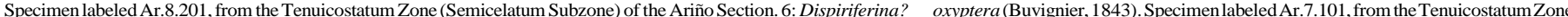

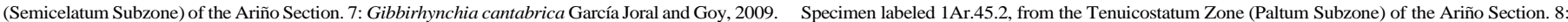

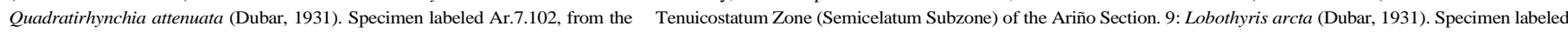

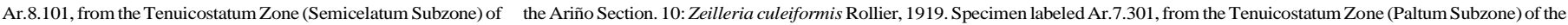
AriñoSection. $(a=$ dorsalview, $b=$ lateral view,$\quad$ and $\mathrm{c}=$ frontal view). The figured specimens are deposited in the collections of the Department of Palaeontology UCM. All photographs (X1). 
Toarcian migrated to the Western European platforms escaping from the high seawater temperatures developed in the areas where they were living, and finally disappeared at the extinction boundary. A marked latitudinal didemic distribution (mainly bipolar) of other benthic organisms, such as bivalves, has been pointed out by many authors (e.g., Damborenea, 1993, 1998, 2002). This didemic distribu- tion is, for some authors, mostly due to temperature (Liu et al., 1998; Westermann, 2000).

Other factors may be important controlling the geographic distri- bution of these organisms. Many authors agree in the importance
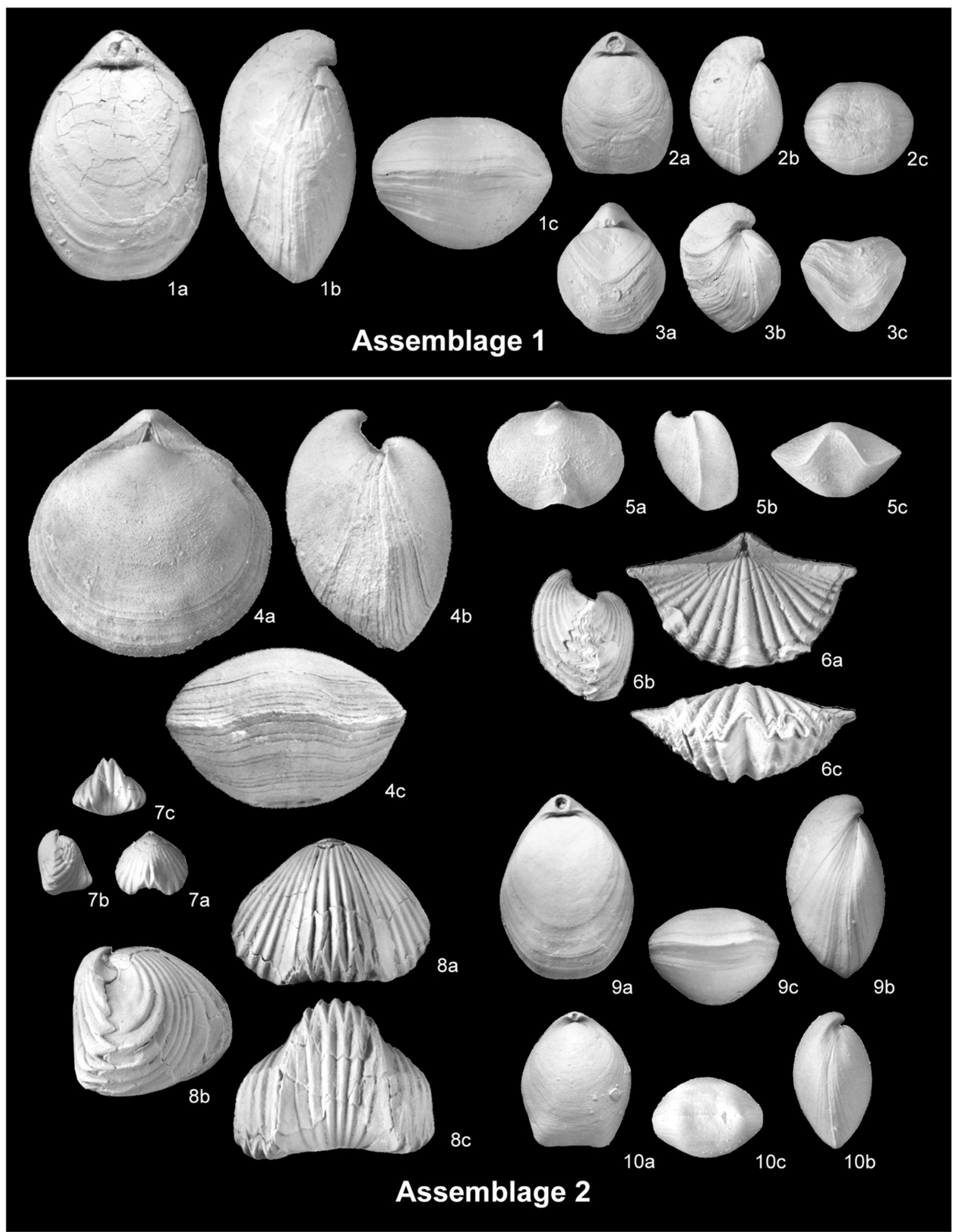
of oceanic currents for most benthic organisms, and more specifically for the brachiopods, since currents strongly determine larval disper- sion (Richardson, 1997). In the case of the Iberian platform system, the southward currents through the Laurasian Seaway hampered northward migration of the benthic organisms toward northern cooler waters, making temperature changes insurmountable events for brachiopods.

The extinction and recovery observed in the brachiopods of this study fit well with the models proposed by Walliser (1986) and other authors (see Twitchett, 2006 for a revision), with an extinction interval, an extinction boundary and a repopulation interval (García Joral et al., 2000; Gahr, 2002, 2005).

\subsection{The extinction interval}

This interval is characterized by an evident relationship between the progressive seawater warming and the progressive brachiopod turnover from assemblage 1 to assemblage 2 . Besides, a marked lati- tudinal gradient in the diversity and in the size of the brachiopods is observed. In the Lower Toarcian Tenuicostatum Zone, brachiopods are less diverse and show an important decrease in size towards the northwestern sections. Taxa number is maximum at the south- ernmost section of Ariño (Figs. 1 and 3), in $\mathrm{La}$ Almunia section, located approximately $90 \mathrm{~km}$ to the northwest (Fig. 1), the number of taxa of assemblages 1 and 2 is still high, but several species such as Liospiriferina falloti, Quadratirhynchia attenuata and Lobothyris arcta present smaller sizes. At the Castrovido section, in the northern Iberian Range, few beds contain brachiopods at the Tenuicostaum Zone. In the Basque-Cantabrian Basin, at the San Andres section, the brachiopod diversity is notably lower (Figs. 2 and 8); only assem- blage 2 is present and it consists of only two species (Gibbirhynchia cantabrica and Zeilleria culeiformis), the two smaller species of as- semblage 2. In the northernmost section (West Rodiles) some species of assemblage 1 are recorded, all of them represented by individuals of a smaller size than in the Iberian Range; assemblage 2 is represented by just one species ( $G$. cantabrica). It is important to emphasize that the smaller sizes observed towards the north is not only due to miniaturization processes, but rather to the northward predominance of the smaller sized taxa. These gradients mark a notable northsouth polarity in the environmental conditions which parallels a progressive deepening of the platform to the north.

Beside this spatial gradient, most species of assemblage 2 in some sections of the Iberian Range, as in Ariño, are present in the upper- most bed before the extinction without a noticeable size decrease or changes in morphology. In fact, some species like Liospiriferina falloti increase their size, the largest specimens often appearing at the upper- most Tenuicostatum Zone, immediately before the final extinction of the order Spiriferinida. A similar pattern is exhibited by Gibbirhynchia cantabrica (cf. García Joral and Goy, 2009, Fig. 5).

Miniaturization within a lineage is a very common phenomenon in brachiopods, and has been related with developmental hetero- chronies linked to environmental stress (cf. Laurin and García Joral, 1990; García Joral and Goy, 1994). In the case described in this paper, the changes observed in the size of the brachiopods show both a spatial gradient, attaining smaller sizes towards the northwest, and a temporal gradient, the larger sizes within several species found in the uppermost Tenuicostatum Zone. Thus, though miniaturization seems to be related in this case to certain environmental constraints, these do not seem to be the same constraints that led to the ex- tinction since spatial and temporal patterns are in disagreement. A similar situation has been described by He et al. (2007) from the Upper Permian at Dongpan, Southern China, where miniaturized forms appear in deep environments before the Permian-Triassic Extinction Event.

In particular, no correlation between the progressive brachiopod turnover and mass extinction and the presence of anoxic environ- ments were observed. Only in the West Rodiles section the extinction boundary coincides with a thinly laminated deposit, indicative of the absence of bioturbation and hence, of the lack of benthic organisms. The deposits of all the remaining sections are strongly bioturbated, revealing the presence of normal oxygen levels. In addition, the low to inexistent values obtained for organic content in most of the sections studied in this paper do not support the presence of euxinic conditions at the time of the extinction interval and at the extinction boundary.

Only in the West Rodiles section the laminated organic facies where the zonal/extinction boundary is included, contain up to 3.2 wt.\% TOC (Gómez et al., 2008). As a consequence, anoxia cannot be argued as the main cause for the brachiopod mass extinction that took place in the EarlyToarcian.

\subsection{The extinction boundary}

The extinction boundary in all the studied sections is located close to the Tenuicostatum-Serpentinum zonal boundary. At this boundary a massive extinction of brachiopods took place (García Joral and Goy, 2000; Gahr, 2002).

From a taxonomical point of view, the effects of this extinction event among the brachiopods are extraordinarily important at a global scale. As a consequence of this event, two major orders, Spiriferinida (ComasRengifo et al., 2006) and Athyridida (Vörös, 2002) disappeared. The order Rhynchonellida suffered a notable renewal and according to Manceñido (2000) about 2/3 of the genera belonging to this order disappeared. The order Terebratulida seems to be less affected, particularly the Superfamily Zeillerioidea.

The extinction undergone by the brachiopods in the Early Toarcian can be considered as the most important turnover in post-Paleozoic times. According to the most updated data of the "Treatise on Invertebrate Paleontology" (Kaesler and Selden, 1997-2007), two of the seven orders, and five of the twelve superfamilies present before the extinction, disappeared. Comparison with other extinction events reveals that only the major latest Permian extinction, in which four orders of brachiopods became extinct, was more severe. No new disappearances of brachiopods at the order level has been recorded since the Early Toarcian, and after this extinction only three superfamilies disappeared, one at the Middle Jurassic, other at the Early Cretaceous and the third one at the latest Cretaceous.

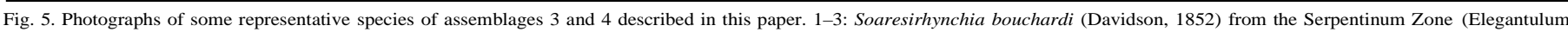

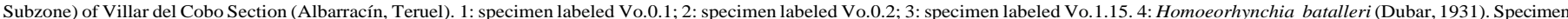

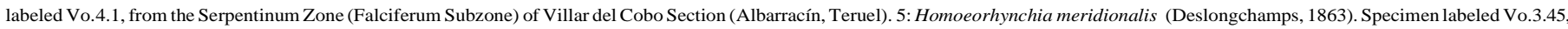

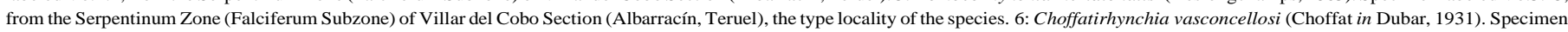

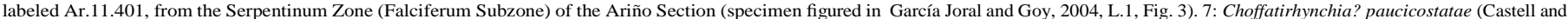

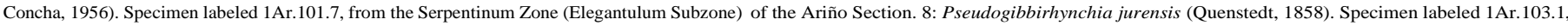

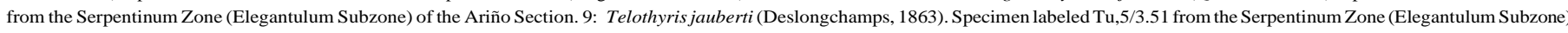

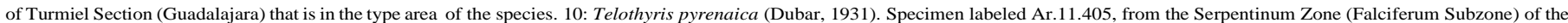

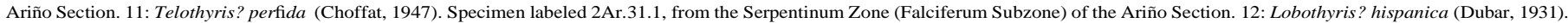

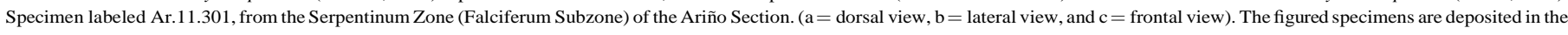
collections of the Department of Paleontology UCM. All photographs (X1). 


\subsection{The repopulation interval}

After the extinction event, brachiopods apparently did not recover in Asturias and in the Basque-Cantabrian Basin until the Middle Toarcian Variablilis Zone (2 Ma after the extinction boundary, following the scale of Ogg, 2004) (García Joral and Goy, 2009). A similar repopulation pattern is recorded throughout most of Western Europe, whereas in the Iberian Range a colonization and diversi- fication phase, representing the repopulation interval, started after a brief episode, of a shorter duration than the equivalent to a subzone, in the order of $0.5 \mathrm{Ma}$. This situation reproduces a similar pattern as observed in the Permian-Triassic Extinction Event, where recovery is
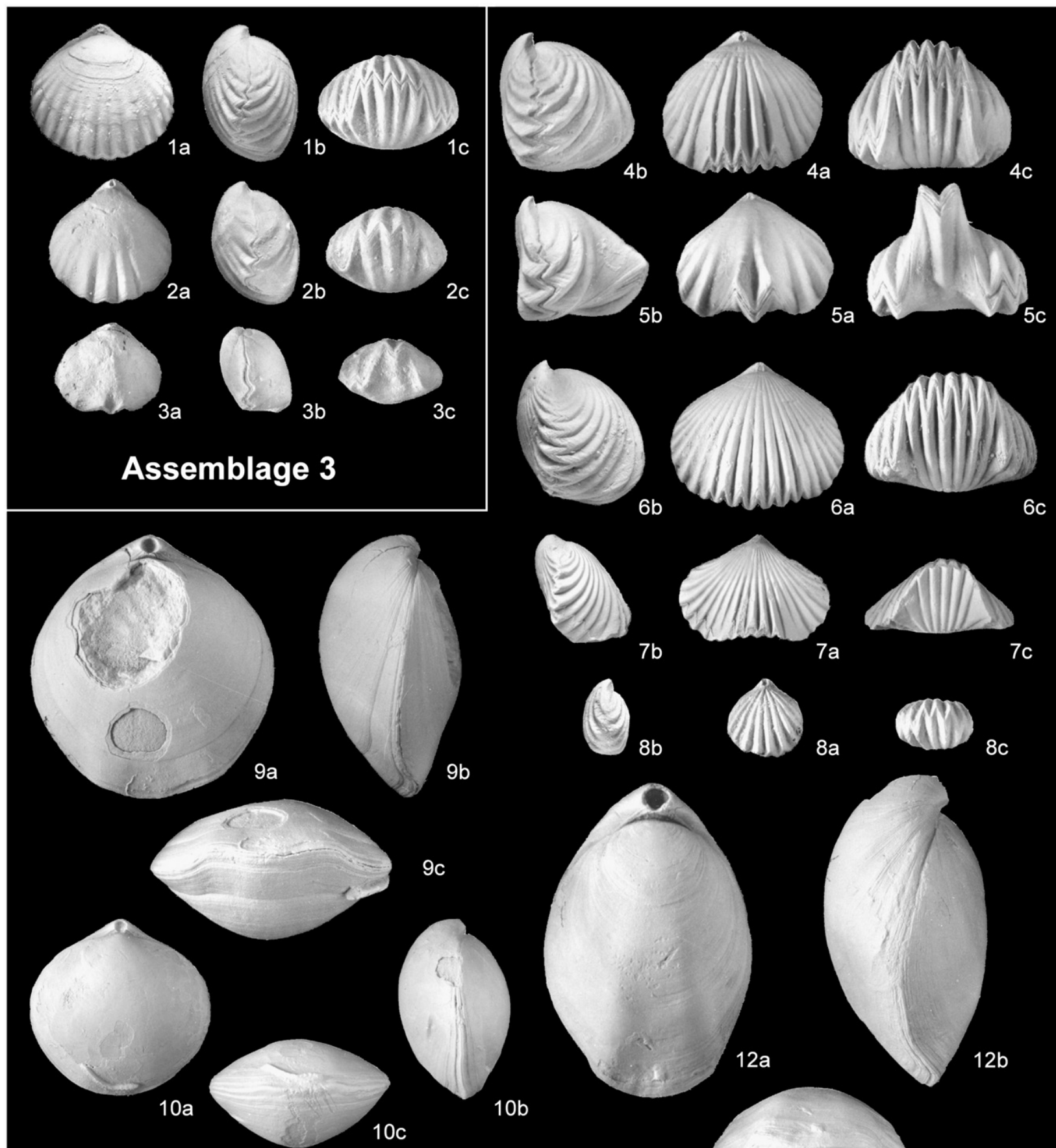

$7 b$

7 a

$7 c$

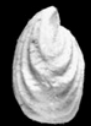

$8 b$
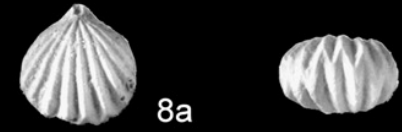

$8 \mathrm{c}$
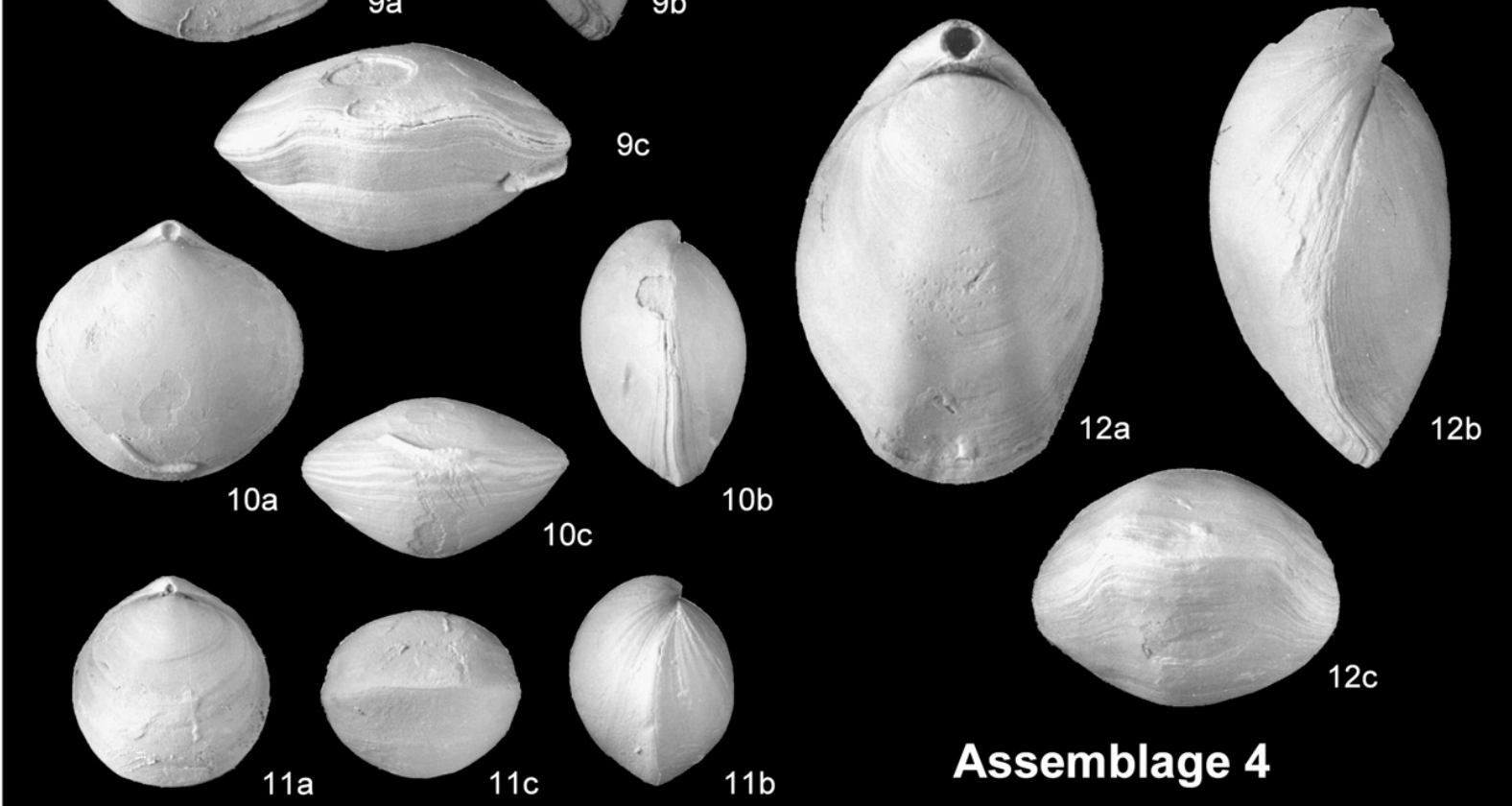

Assemblage 4 

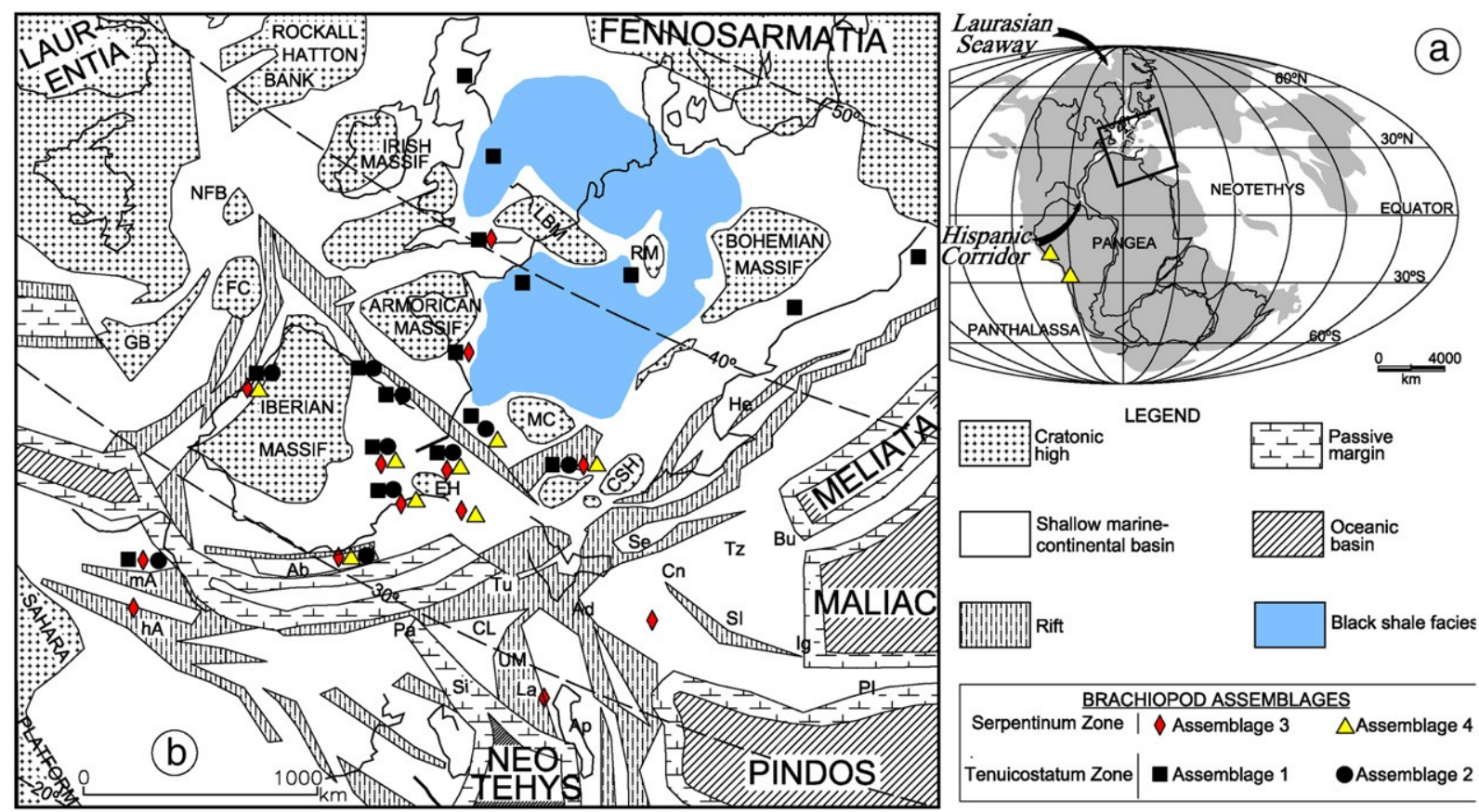

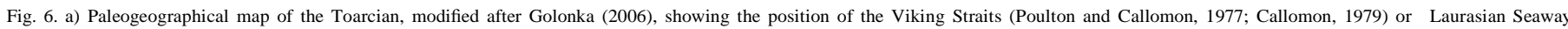

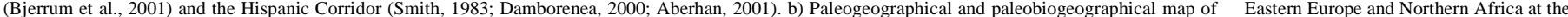

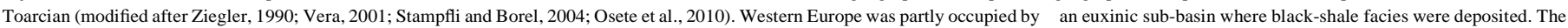

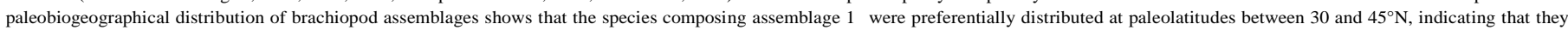

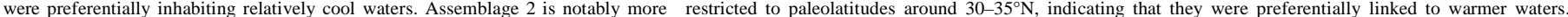

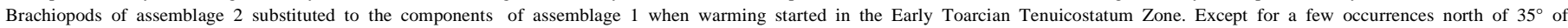
paleolatitude, assemblage 3 constituted by

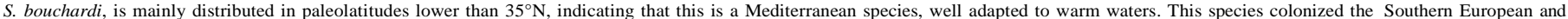

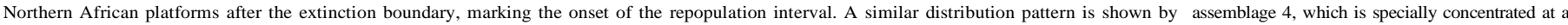

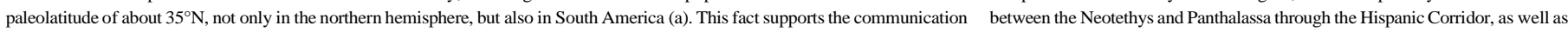

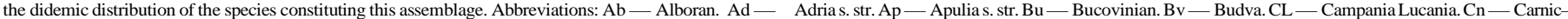

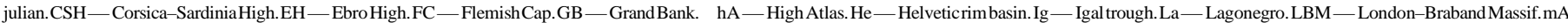

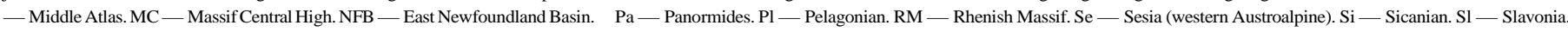
$\mathrm{Tu}$ - Tuscan. Tz — Tisia. UM - Umbria-Marche.

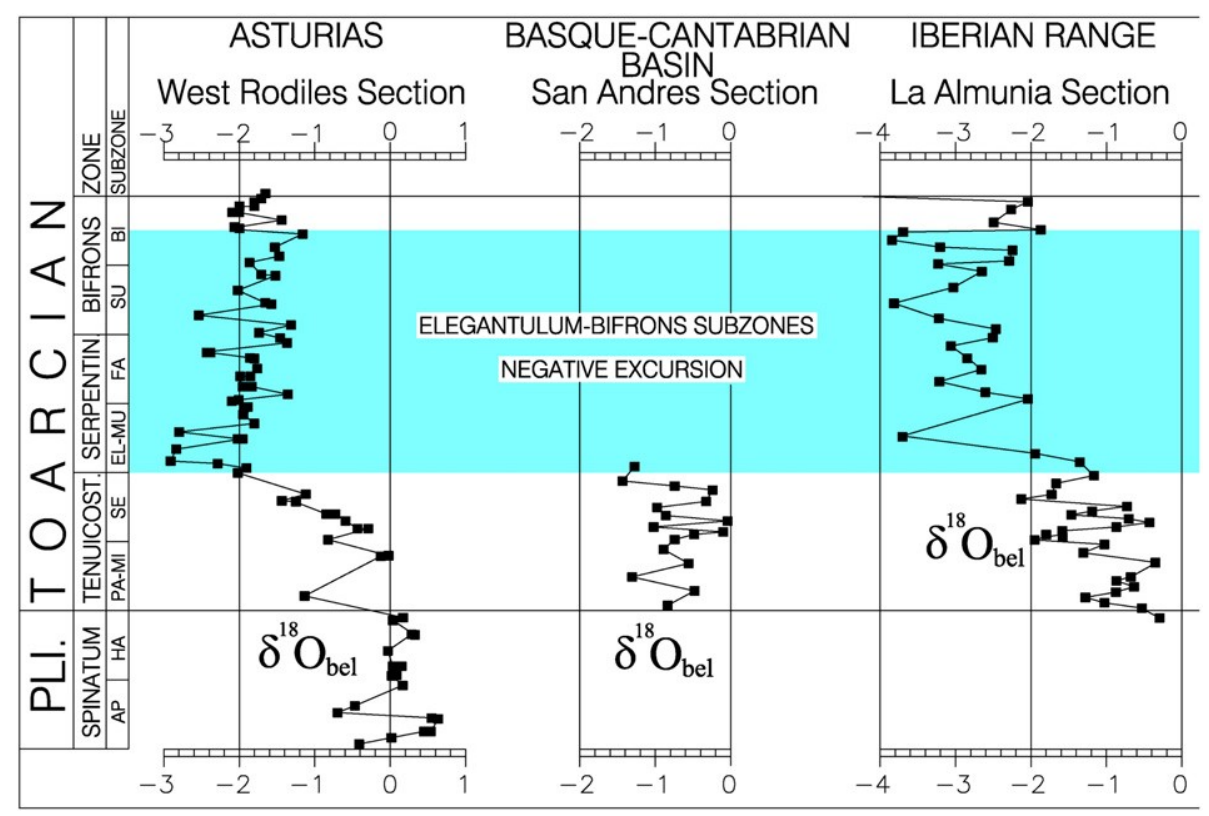

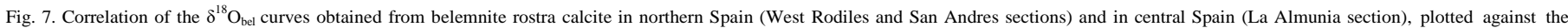
standard ammonite zones and subzones. The $\delta^{18} \mathrm{O}_{\text {bel }}$ values are progressively more negative through the uppermost Pliensbachian (Spinatum Zone)

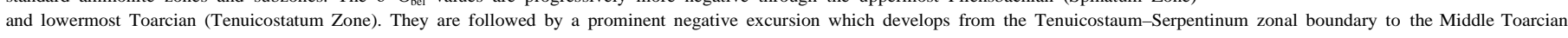

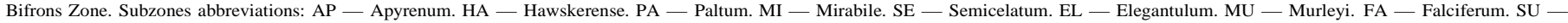
Sublevisoni. BI — Bifrons. 


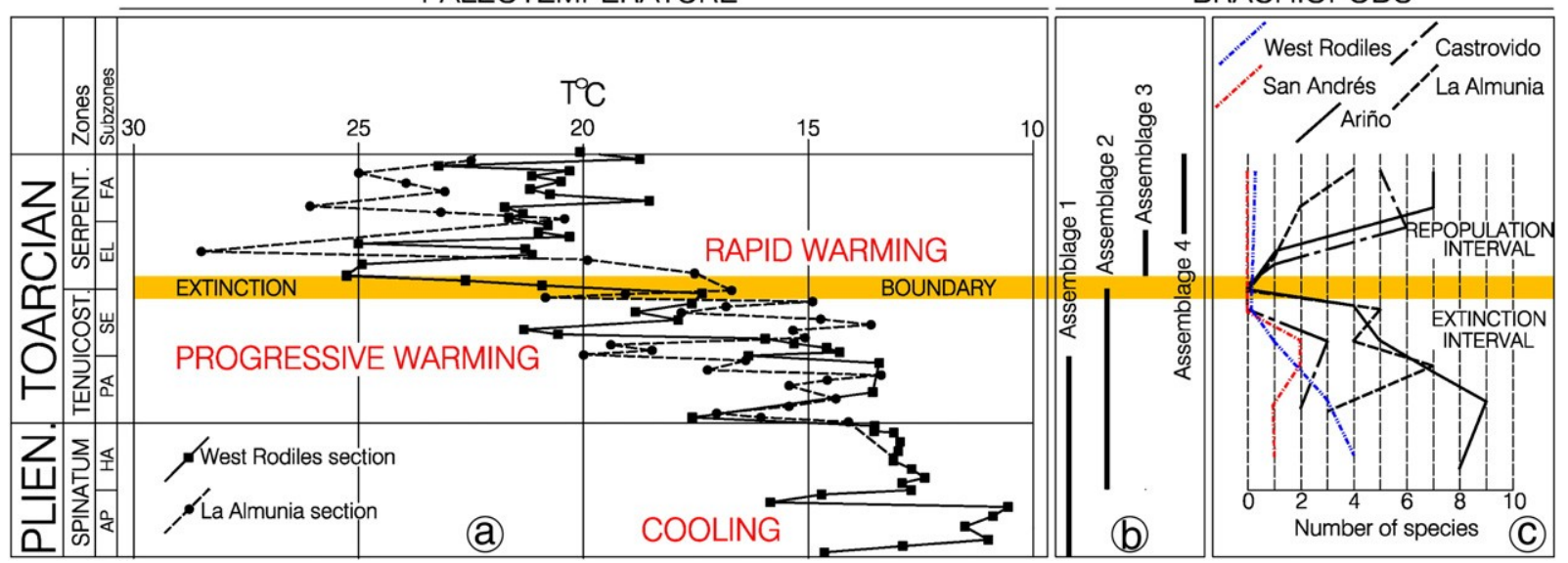

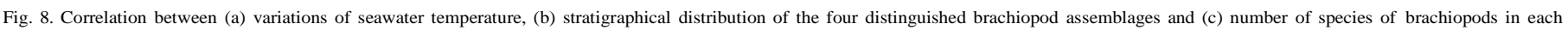

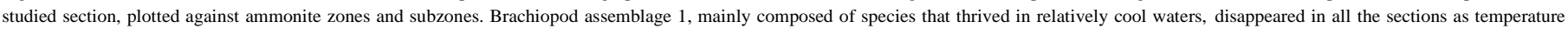

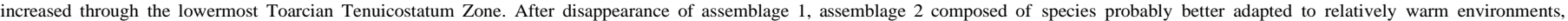

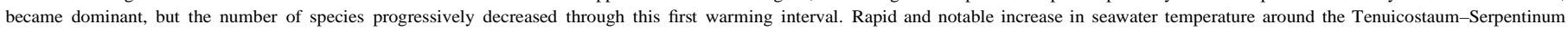

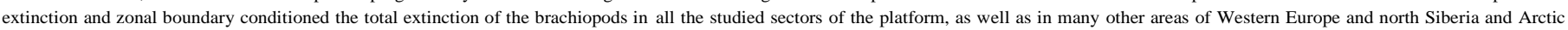

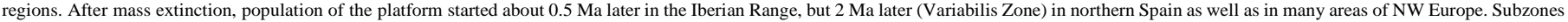
abbreviations: AP — Apyrenum. HA — Hawskerense. PA — Paltum. MI — Mirabile. SE — Semicelatum. EL — Elegantulum. MU — Murleyi. FA — Falciferum. SU — Sublevisoni. BI — Bifrons.

rapid in well oxygenated areas, but delayed in areas affected by anoxia (Twitchett et al., 2004).

The onset of the repopulation interval in the Iberian Range is marked by the presence of numerous and polymorph individuals of Soaresirhynchia bouchardi, rarely associated with Pseudogibbirhynchia jurensis, constituting assemblage 3. S. bouchardi shows a wide geographical distribution (Fig. 6) and a simple morphology, with few derived characters. It forms dense populations within which a high morphological variability can be recognized. All these features correspond with those of an "opportunist" in the sense of Levinton (1970) or Harries et al. (1996, p. 45) occupying an environment where competitors were lacking (García Joral and Goy, 2000; Gahr, 2002, 2005). However, to link assemblage 3 with the "survival interval” of Kauffman-Erwin model as suggested by Gahr $(2002,2005)$ is not adequate, because $S$. bouchardi cannot be considered as a survivor to the extinction, but rather as a colonizer or pioneer marking the onset of the repopulation interval. Based on its external and internal mor- phology, $S$. bouchardi probably derived from some species of the genus Apringia of the Pliensbachian and Toarcian of the Mediterranean area, better adapted to warmer Tethyan environments.

Within the last beds containing Soaresirhynchia bouchardi, several taxa of the so-called Spanish Bioprovince, are progressively recorded, forming assemblage 4. This assemblage mainly includes species of the genera Homoeorhynchia and Telothyris. It reached an important development at the Serpentinum and Bifrons zones, showing more complex morphologies, giving rise to the presence of geographically separate varieties. This is the case of the genus Homoeorhynchia, which shows similar morphologies but with local peculiarities in different parts of the Spanish Bioprovince. Assemblage 4 clearly involves a significant increase in the diversity and in the degree of specialization, thus representing the culmination of the repopulation that started with the colonizers of assemblage 3.

\section{Conclusions}

Calculated seawater paleotemperatures from the $\delta^{18} \mathrm{O}$ values obtained in belemnite rostra calcite, shows a notable seawater warming interval during the Early Jurassic that started around the Pliensbachian-Toarcian boundary, when relatively cool temperatures have been inferred. Temperatures progressively increased during the
Early Toarcian Tenuicostatum Zone and suffered a notable and rapid increased during the Tenuicostatum-Serpentinum zonal boundary.

The dynamics of the brachiopod assemblages studied in central and northern Spain show an excellent correlation with the detected climate change. During the latest Pliensbachian cooling interval, a group of brachiopods here referred to as assemblage 1, thrived under favorable lower seawater temperature conditions. As temperatures rose, through the Tenuicostatum Zone, assemblage 1 was replaced by assemblage 2 which become dominant in all the studied area up to the extinctionboundary.

Coinciding with the rapid and pronounced increase in temperature recorded around the Tenuicostatum-Serpentinum zonal boundary, brachiopods disappeared. This extinction event is synchronous not only in the studied area, but also in the whole of Western Europe, and probably in Northern Siberia and the Arctic region. The extinction event appears to be clearly independent from sea bottom oxygenation conditions, as extinction is recorded both in areas where the basin had euxinic conditions as well as in areas where waters were well oxygenated, suggesting a different cause for the extinction other than sea bottom anoxia.

The notable increase in seawater temperature recorded at the Tenuicostatum Zone and the rapid and notable warming interval that started around the Tenuicostatum-Serpentinum zonal boundary are the most plausible causes of the mass extinction. The predominant southward currents along the Laurasian Seaway (or Viking Straits) obstructed or precluded the dispersion of the brachiopods living in the Western Tethys epicontinental platforms toward the northern and cooler Arctic waters. These severe changes in the environmental conditions caused a massive extinction of most of the benthos.

The taxonomical impact of this extinction for the brachiopods at a global scale is very significant. It represents the disappearance of two orders, the Spiriferinida and Athyridida, together with the dis- appearance of around $70 \%$ of the genera of the order Rhynchonellida and an important renewal of the order Terebratulida. The extinction event occurred when many of these groups, at least locally, showed a relatively high diversity, including both generalists as well as specialized taxa.

The recovery pattern of the brachiopods after the extinction event is in agreement with the classic models of extinction-pause- radiation, and constitutes a good example of these evolutionary processes. The time of recovery is relatively short at the Iberian Range 
of central Spain (around 0.5 Ma). The approximately $2 \mathrm{Ma}$ lag-time observed both in Northern Spain as in Western Europe in the recovery of the brachiopods (Early Toarcian Serpentinum Zone to Middle Toarcian Variabilis Zone), is probably linked to the persistence of unfavorable environmental conditions in these areas. In the case of the euxinic sub-basin located in Central Europe, anoxia could be one of the main causes for the delay in the recovery, as laminated black-shale facies persist until the Middle Toarcian.

\section{Acknowledgements}

This research work was financed by projects CGL 2008-03112 and CGL 2008-01273 of the Spanish Ministerio de Educación y Ciencia, and the projects GR58/08B/910431, GR58/08A/910429 and GR58/08A/ 91039 of the Universidad Complutense de Madrid. We gratefully acknowledge Editor F. Surlyk, and reviewers M. Manceñido and A. Vörös for their valuable comments and constructive reviews.

\section{References}

Aberhan, M., 2001. Bivalve palaeobiogeography and the Hispanic Corridor: time of opening and effectiveness of a proto-Atlantic seaway. Palaeogeogr. Palaeoclimatol. Palaeoecol. 165, 375-394.

Aberhan, M., Fürsich, F.T., 1997. Diversity analysis of Lower Jurassic bivalves of the Andean Basin and the Pliensbachian-Toarcian mass extinction. Lethaia 29, 181-195.

Aberhan, M., Baumiller, T.K., 2003. Selective extinction among Early Jurassic bivalves: a consequence of anoxia. Geology 31, 1077-1080.

Ager, D.V., 1965. The adaptation of Mesozoic brachiopods to different environments. Palaeogeogr. Palaeoclimatol. Palaeoecol. 1, 143-172.

Ager, D.V., 1967. Some Mesozoic brachiopods in the Tethys region. Aspects of Tethyan Biogeography: In: Ager, D.V., Adams, C.G. (Eds.), Syst. Assoc. Publ., 7, pp. 135-151. Ager, D.V. 1971. Space and time in brachiopod history. Faunal Provinces in Space and Time: In: 4, pp. 95-110.

Ager, D.V., 1978. The stratigraphical distribution of Jurassic Brachiopoda. Recent Res. Geol. Delhi 4, 6-21.

Al-Suwaidi, A.H., Angelozzi, G.N., Baudin, F., Damborenea, S.E., Hesselbo, S.P., Jenkyns, H.C., Manceñido, M.O., Riccardi, A.C., 2010. First record of the Early Toarcian Oceanic Anoxic Event from the Southern Hemisphere, Neuquén Basin, Argentina. J. Geol. Soc. Lond. 167, 633-636.

Alméras, Y., 1996. Les Brachiopodes toarciens et aaléniens inférieurs du Bassin du Rhône. Paléntologie et biostratigraphie. Revisión de la collection Dumortier et compléments. Doc. Lab. Géol. Lyon $138,1-123$.

Alméras, Y., Becaud, M., 2002. Les zones charnières entre provinces paléobiogéographi- ques. L'exemple des Brachiopodes de la bordure sud du Massif armoricain (France) au Toarcien. Géol. Fr. 3, 17-29.

Alméras, Y., Fauré, P., 2000. Les Brachiopodes liasiques des Pyrénées. Paléontologie, Biostratigraphie, Paléobiogéographie et Paléoenvironnements. Strata 36, 1-395.

Alméras, Y., Moulan, G., 1982. Les térébratulides liasiques de Provence (Paléontologie, Biostratigraphie, Paléoécologie, Phylogénie). Doc. Lab. Géol. Lyon 86, 1-365.

Alméras, Y., Mouterde, R., Benest, M., Elmi, S., Bassoullet, J.P., 1996. Les Brachiopodes toarciens de la rampe carbonatée de Tomar (Portugal). Doc. Lab. Géol. Lyon 138, 125-191.

Alméras, Y., Boullier, A., Laurin, B., 1997. Zonation du Jurassique français par les Brachiopodes. Biostratigraphie du Jurassique ouest-européen et méditerranéen : zonations parallèles et distribution des invertébrés et microfossiles: In: Cariou, E., Hantzpergue, P. (Eds.), Bull. Centre Rech. Elf Explor. Prod., 17, pp. 169-195.

Álvaro, M., Barnolas, A., Cabra, P., Comas-Rengifo, M.J., Fernández-López, S.R., Goy, A., 1989. El Jurásico de Mallorca (Islas Baleares). Cuad. Geol. Ibér. 13, 67-120.

Anderson, T.F., Arthur, M.A., 1983. Stable isotopes of oxygen and carbon and their application to sedimentologic and paleoenvironmental problems. Stable Isotopes in Sedimentary Geology: In: Arthur, M.A. (Ed.), SEPM Short Course, 10, pp. 1-1-1-151.

Arias, C., 2006. Northern and Southern Hemisphere ostracod palaeobiogeography during the Early Jurassic: possible migration routes. Palaeogeogr. Palaeoclimatol. Palaeoecol. 233, 6395.

Arias, C., 2007. Pliensbachian-Toarcian ostracod biogeography in NW Europe: evidence for water mass structure evolution. Palaeogeogr. Palaeoclimatol. Palaeoecol. 251, 398-421.

Arias, C.F., Comas-Rengifo, M.J., Goy, A., Herrero, C., Ruget, C., 1992. Variations dans les associations de brachiopodes, foraminifères et ostracodes du Toarcien basal dans un secteur central de la Cordillère Ibérique. Un exemple dans la "Rambla del Salto" (Teruel, Espagne). Cah. Univ. Cathol. Lyon Sér Sci. 5, 5-25.

Baeza-Carratalá, J.F., 2008. Patrimonio Paleontológico en la Colección Jiménez de Cisneros y su aplicación al estudio de los braquiópodos del Jurásico Inferior en la Cordillera Bética Oriental (Provincias de Alicante y Norte de Murcia). Unpublished Doctoral Thesis, University of Alicante, 906 p.

Bailey, T.R., Rosenthal, Y., McArthur, J.M., van de Schootbrugge, B., Thirlwall, M.F., 2003. Paleoceanographic changes of the Late Pliensbachian-Early Toarcian interval: a possible link to the genesis of an Oceanic Anoxic event. Earth Planet. Sci. Lett. 212, 307-320.

Bassoullet, J.P., Baudin, F., 1994. Le Toarcien inférieur: une période de crise dans les bassins et sur les plate-formes carbonatées de l'Europe du Nord-Ouest et de la Téthys. Geobios. Mém. Spec. 17, 645-654.

Bizon, G., Champetier, Y., Guérin-Franiatte, S., Rollet, A., 1966. Présence de Bouleiceras nitescens dans l'est des Cordillières bétiques. Bull. Soc. Géol. Fr. 8, 901-904.

Bjerrum, C.J., Surlyk, F., Callomon, J.H., Slingerland, R.L., 2001. Numerical paleoceano- graphic study of the Early Jurassic Transcontinental Laurasian Seaway. Paleocea- nography 16, 390404.

Callomon, J.H., 1979. Marine boreal Bathonian fossils from the northern North Sea and their palaeogeographical significance. Proc. Geol. Assoc. Lond. 90, 163-169.

Cecca, F., Macchioni, F., 2004. The two Early Toarcian (Early Jurassic) extinction events in ammonoids. Lethaia 37, 35-56.

Choffat, P., 1880. Etude stratigraphique et paléontologique des terrains jurassiques du Portugal. 1ère livr.: Le Lias et le Dogger au Nord du Tage. Mém. Serv. Tr. Géol. Portugal, . 72.

Comas-Rengifo, M.J., Goy, A., Yébenes, A., 1988. El Lias en el Sector Suroccidental de la Sierra de la Demanda (Castrovido, Burgos). Cienc. Tierra Geol. 11, 119-141.

Comas-Rengifo, M.J., García Joral, F., Goy, A., 2006. Spiriferinida (Brachiopoda) del Jurásico Inferior del NE y N de España: distribución y extinción durante el evento anóxico oceánico del Toarciense inferior. Bol. R. Soc. Esp. Hist. Nat. (Sec. Geol.) 101, 147-157.

Damborenea, S.E., 1993. Early Jurassic South American pectinaceans and circum-Pacific palaeobiogeography. Palaeogeogr. Palaeoclimatol. Palaeoecol. 100, 109-123.

Damborenea, S.E., 1998. The bipolar bivalve Kolymonectes in South America and the diversity of the Propeamussiidae in Mesozoic times. In: Johnston, P.A., Haggart, J.W. (Eds.), Bivalves: an Eon of Evolution. University of Calgary Press, pp. 143-155.

Damborenea, S.E., 2000. Hispanic Corridor: its evolution and the biogeography of bivalve molluscs. Advances in Jurassic Research 2000: In: Hall, R.L., Smith, P.L. (Eds.), Proceedings of the Fifth International Symposium on the Jurassic System, Georesearch Forum, 6, pp. 369-380.

Damborenea, S.E., 2002. Jurassic evolution of Southern Hemisphere marine palaeobio- geographic units based on benthonic bivalves. Geobios 35 (M.S. 24), 51-71.

Davidson, T., 1852. British Fossil Brachiopoda, Oolitic and Liasic species, Vol. 1, Part 3, No. 2. Palaeontographical Society Monograph, pp. 65-100.

Delance, J.H., 1972. Problèmes posés par la variation géographique des espèces, leurs implications stratigraphiques. Exemples pris chez les brachiopodes jurassiques. Mémoires du B.R.G.M., 77, pp. 69-76.

Delance, J.H., 1974. Zeilleriidés du Lias d'Europe occidentale (Brachiopodes). Systéma- tique des populations. Phylogénie. Biostratigraphie. Mém. Géol. Univ. Dijon 2, 1-408.

Dera, G., Pucéat, E., Pellenard, P., Neige, P., Delsate, D., Joachimski, M.M., Reisberg, L., Martinez, M., 2009. Water mass exchange and variations in seawater temper- ature in the NW Tethys during the Early Jurassic: evidence from neodymium and oxygen isotopes of fish teeth and belemnites. Earth Planet. Sci. Lett. 286, 198-207.

Dommergues, J.-L., Meister, C., Mouterde, R., 1997. Pliensbachien. Biostratigraphie du Jurassique ouest-européen et méditerranéen : zonations parallèles et distribution des invertébrés et microfossiles: In: Cariou, E., Hantzpergue, P. (Eds.), Bull. Centre Rech. Elf Explor. Prod., 17, pp. 15-23.

Dubar, G., 1931. Brachiopodes liasiques de Catalogne et des régions voisines. Bull. Inst. Catalana Hist. Nat. 31, 103-180.

Elmi, S., Alméras, Y., Ameur, M., Benhamou, M., 1985. Précisions biostratigraphiques et paléoécologiques sur le Lias des environs de Tiffrit (Saïda, Algérie occidentale). Cah. Univ. Cathol. Lyon 14, 15-41.

Elmi, S., Alméras, Y., Benshili, K., 1991. Influence de l'évolution paléogéographique sur les peuplements au cours du Lias dans le Moyen-Atlas Marocain. Sci. Géol. Mém. 83, 115-131.

Elmi, S., Roulleau, L., Gabilly, J., Mouterde, R., 1997. Toarcien. Biostratigraphie du Jurassique ouest-européen et méditerranéen : zonations parallèles et distribution des invertébrés et microfossiles: In: Cariou, E., Hantzpergue, P. (Eds.), Bull. Centre Rech. Elf Explor. Prod., 17, pp. 25-36.

Fernández-López, S., García Joral, F., Gómez, J.J., Henriques, M.H.P., Martínez, G., 1998. La diferenciación paleogeográfica de la Cuenca Catalana al principio del Jurásico Medio. Rev. Soc. Geol. Esp. 11, 3-22.

Gahr, M.E., 2002. Palökologie des Makrobenthos aus dem Unter-Toarc SW-Europas. Beringeria 31, 3-204.

Gahr, M., 2005. Response of Lower Toarcian (Lower Jurassic) macrobenthos of the Iberian Peninsula to sea level changes and mass extinction. J. Iberian Geol. 31, 197-215.

García Joral, F., Goy, A., 1984. Características de la fauna de braquiópodos del Toarciense Superior en el Sector Central de la Cordillera Ibérica (Noreste de España). Est. Geol. 40, 55-60.

García Joral, F., Goy, A., 1994. The associations of brachiopods from the Toarcian-Aalenian transition in the Fuentelsaz section (Iberian Range, Spain). 3ème Symposium International de Stratigraphie du Jurassique: In: Cariou, E., Hantzpergue, P. (Eds.), Geobios, Mém Sp., 17, pp. 223-228.

García Joral, F., Goy, A., 2000. Stratigraphic distribution of Toarcian brachiopods from the Iberian Range (Spain) and its relation to depositional sequences. Advances in Jurassic Research 2000: In: Hall, R.L., Smith, P.L. (Eds.), Proceedings of the Fifth International Symposium on the Jurassic System, Georesearch Forum, 6, pp. 381-386.

García Joral, F., Goy, A., 2004. Caracterización de Choffatirhynchia nov. gen. (Brachiopoda, Rhynchonellida) en el Toarciense (Jurásico) de la Cordillera Ibérica (España). Bol. R. Soc. Esp. Hist. Nat. (Geol.) 99, 237-250. 
García Joral, F., Goy, A., 2009. Toarcian (Lower Jurassic) brachiopods in Asturias (Northern Spain) stratigraphic distribution, critical events and palaeobiogeography. Geobios 42, 255-264.

García Joral, F., Goy, A., De Renzi, M., 2000. Extinction and recovery of the brachiopods in the Lower Toarcian (Jurassic) of $\mathrm{N}$ and NE Spain. In: Brunton, $\mathrm{H}$. (Ed.), The Millennium Brachiopod Congress. Abstracts Volume, p. 35.

García-Ramos, J.C., Valenzuela, M., SuárezdeCenti, C., 1992. Icnofósiles, procesos sedimentarios y facies en una rampa carbonatada del Jurásico de Asturias, Sociedad Geológica de España. Reunión monográfica sobre Biosedimentación. Universidad de Oviedo, pp. 5-89. Georgescu, D.M., 1990. An attempt to the correlation of the brachiopod biozones in the Liassic deposits of the Northern Apuseni Mountains (Romania). Crisia 20, 517-541. Golonka, J., 2006 Late Triassic and Early Jurassic palaeogeography of the world. Palaeogeogr. Palaeoclimatol. Palaeoecol. 244, 297-307.

Gómez, J.J., Arias, C., 2010. Rapid warming and ostracods mass extinction at the Lower Toarcian (Jurassic) of central Spain. Mar. Micropaleontol. 74, 119-135.

Gómez, J.J., Goy, A., 2010. Early Toarcian (Early Jurassic) mass extinction linked to warming in Northern and Central Spain. Comparison with other sections of Western Europe. Earth Sci. Frontiers. Spec. Publ. 17, 374-375.

Gómez, J.J., Comas-Rengifo, M.J., Goy, A., 2003. Las unidades litoestratigráficas del Jurásico inferior de las cordilleras Ibérica y Costero Catalana. Rev. Soc. Geol. Esp.16 (3-4), 227-237.

Gómez, J.J., Goy, A., Canales, M.L., 2008. Seawater temperature and carbon isotope variations in belemnites linked to mass extinction during the Toarcian (Early Jurassic) in Central and Northern Spain. Comparison with other European sections. Palaeogeogr. Palaeoclimatol. Palaeoecol. 258, 28-58.

Goy, A., Martínez, G., 1990. Biozonación del Toarciense en el sector central de la Cordillera Ibérica. Cuad. Geol. Ibér. 14, 11-53.

Goy, A., Gómez, J.J., Yébenes, A., 1976. El Jurásico de la Rama Castellana de la Cordillera Ibérica (Mitad Norte) I. Unidades litoestratigráficas. Est. Geol. 32, 391-423.

Goy, A., Martínez, G., Ureta, S., 1994. El Toarciense de la Región de Pozazal-Reinosa (Cordillera Cantábrica, España). Coloquios Paleontología 46, 93-127.

Goy, A., Martínez, G., Arias, C., Bernad, J., García Joral, F., Gómez, J.J., Herrero, C., Perilli, N., Ureta, S., 1996. The Toarcian in the sector located between La Almunia de Doña Godina and Ricla. In: Ureta, S. (Ed.), 1st Toarcian and 4th Aalenian Working Groups Meeting. FieldTrip Iberian Rang Guide-Book. Department of Paleontology Universidad Complutense de Madrid, pp. 3-23.

Goy, A., García Joral, F., Gómez, J.J., Martínez, G., Ureta, S., 1997. El Toarciense en la región de Ariño. Rama Aragonesa de la Cordillera Ibérica, España. In: Meléndez, G., Pérez-Urresti,

I. (Eds.), IV Congreso de Jurásico de España. Comunicaciones, pp. 79-80.

Goy, A., Comas-Rengifo, M.J., Arias, C., García Joral, F., Gómez, J.J., Herrero, C., Martínez, G., Rodrigo, A., 1998. El Tránsito Pliensbachiense/Toarciense en el Sector Central de la Rama Aragonesa de la Cordillera Ibérica (España). Cah. Univ. Cathol. Lyon 10, 159-179. Graziano, R., Buono, G., Tadde Ruggiero, E., 2006. Lower Toarcian (Jurassic) brachiopod-rich carbonate facies of the Gran Sasso rang Ital. 45, 61-74.

(central Apennines, Italy). Boll. Soc. Paleontol.

Hallam, A. 1971. Mesozoic geology and the opening of the North Atlantic. J. Geol. 79, 129-157.

Hallam, A., 1986. The Pliensbachian and Tithonian extinction events. Nature 319, 765-768.

Hallam, A., 1987. Radiations and extinctions in relation to environmental change in the marine Jurassic of North West Europe. Paleobiology 13, 152-168.

Harries, P.J., Little, C.T.S., 1999. The Early Toarcian (Early Jurassic) and the Cenomanian- Turonian (Late Cretaceous) mass extinctions: similarities and contrasts. Palaeo- geogr. Palaeoclimatol Palaeoecol. 154, 39-66.

Harries, P.J., Kauffman, E.G., Hansen, T.A., 1996. Models for Biotic Survival Following Mass Extinction. Biotic recovery from mass extinction events: In: Hart, M.B. (Ed.), Geol. Soc. Special Publication, 102, pp. 41-60.

He, W., Shi, G.R., Feng, Q., Campi, M.J., Gu., S., Bu., J., Peng, Y., Meng, Y., 2007. Brachiopod miniaturization and its possible causes during the Permian-Triassic crisis in deep wate environments, South China. Palaeogeogr. Palaeoclimatol. Palaeoecol. 252, 132-144.

Jenkyns, H.C., 1985. The early Toarcian and Cenomanian-Turonian anoxic events in Europe: comparisons and contrasts. Geol. Rundsch. 74, 505-518.

Jenkyns, H.C., 1988. The early Toarcian (Jurassic) anoxic event: stratigraphic, sedimentary and geochemical evidence. Am. J. Sci. 288, 101-151.

Jenkyns, H.C., 1999. Mesozoic anoxic events and palaeoclimate. Zbl. Geol. Paläont. 7-9, 943-949.

Jenkyns, H.C., 2003. Evidence for rapid climate change in the Mesozoic-Palaeogene greenhouse world. Philos. Trans. R. Soc. Lond. A 361, 1885-1916.

Jenkyns, H.C., Clayton, C.J., 1986. Black shales and carbon isotopes in pelagic sediments from the Tethyan Lower Jurassic. Sedimentology 33, 87-106.

Jenkyns, H.C., Clayton, C.J., 1997. Lower Jurassic epicontinental carbonates and mudstones from England and Wales: chemostratigraphic signals and the early Toarcian anoxic event. Sedimentology 44, 687-706.

Jenkyns, H.C., Géczy, B., Marshall, J.D., 1991. Jurassic manganese carbonates of central Europe and the early Toarcian anoxic event. J. Geol. 99, 137-149.

Jenkyns, H.C., Gale, A.S., Corfield, R.M., 1994. Carbon- and oxygen-isotope stratigraphy of the English Chalk and Italian Scaglia and its palaeoclimatic significance. Geol. Mag. 131, 1-34.

Jenkyns, H.C., Gröcke, D., Hesselbo, S.P., 2001. Nitrogen isotope evidence for water mass denitrification during the early Toarcian Oceanic Anoxic Event. Paleoceanography 16, 593603.

Jenkyns, H.C., Jones, C.E., Gröcke, D.R., Hesselbo, S.P., Parkinson, D.N., 2002 Chemostratigraphy of the Jurassic System: application, limitations and implications for palaeoceanography. J. Geol. Soc. Lond. 159, 351-378.
Jiménez, A.P., Jiménez de Cisneros, C., Rivas, P., Vera, J.A., 1996. The Early Toarcian Anoxic Event in the Westernmost Tethys (Subbetic): paleogeographic and paleobiogeographic significance. J. Geol. 104, 399-416.

Kaesler, R.L., Selden, P.A. (Eds.), 1997-2007. Treatise on Invertebrate Paleontology. Part H, Brachiopoda, Revised, Vols. 1-6. Geological Society of America \& Paleontological Institute, Boulder, Colorado \& Lawrence, Kansas.

Kauffman, E.G., Erwin, D.H., 1995. Surviving mass extinctions. Geotimes 14, 14-17.

Laurin, B., García Joral, F., 1990. Miniaturization and heterochrony in Homoeorhynchia meridionalis and $H$. cynocephala (Brachiopoda, Rhynchonelidae) from the Jurassic of the Iberian Range, Spain. Paleobiology 16, 62-76.

Levinton, J.S., 1970. The paleoecological significance of opportunistic species. Lethaia 3, 69-78.

Little, C.T.S., Benton, M.J., 1995. Early Jurassic mass extinction: a global long-term event. Geology 23, 495-498.

Liu, C., Heinze, M., Fürsich, F.T., 1998. Bivalves provinces in the Proto-Atlantic and along the southern margin of the Tethys in the Jurassic. Palaeogeogr. Palaeoclimatol. Palaeoecol. $137,127-151$

Mailliot, S., Mattioli, E., Guex, J., Pittet, B., 2006. The Early Toarcian anoxia, a synchronous event in the Western Tethys? An approach by quantitative biochronology (Unitary Associations), applied on calcareous nannofossils. Palaeogeogr. Palaeoclimatol. Palaeoecol. 240, 562-586.

Mailliot, S., Mattioli, E., Bartolini, A., Baudin, F., Pittet, B., Guex, J., 2008. Late Pliensbachian- Early Toarcian (Early Jurassic) environmental changes in an epicontinental basin of NW Europe (Causses area central France): a micropaleontological and geochemical approach. Palaeogeogr. Palaeoclimatol. Palaeoecol. 273, 346-364.

Manceñido, M.O., 1990. The succession of Early Jurassic brachiopod faunas from Argentina: correlation and affinities. In: MacKinnon, D.I., Lee, D.E., Campbell, J.D. (Eds.), Brachiopods through Time. : Proceedings Second International Brachiopod Congress. A.A. Balkema, Rotterdam, pp. 397-404

Manceñido, M.O., 2000. A systematic summary of the stratigraphic distribution of Jurassic rhynchonellide genera (brachiopoda). Advances in Jurassic Research 2000: In: Hall, R.L., Smith, P.L. (Eds.), Proceedings of the Fifth International Symposium on the Jurassic System, GeoResearch Forum, 6, pp. 387-396.

Manceñido, M.O., 2002. Paleobiogeography of Mesozoic brachiopod faunas from AndeanPatagonian areas in a global context. Geobios 35 (M.S. 24), 176-192.

Manceñido, M.O. Dagys, A.S., 1992. Brachiopods of the circum-Pacific region. In: Westermann, G.E.G. (Ed.), The Jurassic of the Circum-PacificWorld and Regional Geology, 3. Cambridge Univ. Press, pp. 328-333.

Mattioli, E., Pittet, B., Bucefalo Palliani, R., Röhl, H.J., Schmid-Röhl, A., Morettini, E., 2004. Phytoplankton evidence for the timing and correlation of palaeoceanographical changes during the early Toarcian oceanic anoxic event (Early Jurassic). J. Geol. Soc. Lond. 161, 685-693.

Mattioli, E., Pittet, B., Pettpierre, L., Mailliot, S., 2009. Dramatic decrease of pelagic carbonate production by nannoplanton across the Early Toarcian anoxic event (T-OAE). Glob. Planet. Change 65, 134145.

McArthur, J.M., Donovan, D.T., Thirlwall, M.F., Fouke, B.W., Mattey, D., 2000. Strontium isotope profile of the early Toarcian (Jurassic) oceanic anoxic event, the duration of ammonite biozones, and belemnite palaeotemperatures. Earth Planet. Sci. Lett. 179, 269-285.

McArthur, J.M., Algeo, T.J., van de Schootbrugge, B., Li, Q., Howart, R.J., 2008. Basinal restriction, black shales, Re-Os dating, and Early Toarcian (Jurassic) oceanic anoxic event. Paleoceanography 23, Pa4217. doi:10.1092/2008PA001607.

Metodiev, L., Koleva-Rekalova, E., 2008. Stable isotope records $\left(\delta^{18} \mathrm{O}\right.$ and $\left.\delta^{13} \mathrm{C}\right)$ of Lower-Middle Jurassic belemnites from the Western Balkan mountains (Bulgaria): palaeoenvironmental application. Appl. Geochem. 23, 2845-2856.

Middlemiss, F.A.,1984 Distribution of Lower Cretaceous Brachiopods and itsrelation to climate. In: Brenchley, P.J. (Ed.), Fossils and Climate. Wiley, London, pp. 165-170. Nikitenko, B.L., 2008. The Early Jurassic to Aalenian paleobiogeography of the Arctic realm: implications of microbenthos

Correlation 16, 50-80.

Nikitenko, B.L., Shurygin, B.N., 1994. Lower Toarcian black shales and Pliensbachian- Toarcian crisis of the biota of Siberian Paleoseas. 1992 Proc. Int. Con. Artic Margins, U.S. Dep.Int min. Manag. Serv. Alaska Outer Cont. Shelf Region, Anchorage, USA, pp. 39-45.

NOAA, a. http://www.noaa.gov/cgi-biu/oc5/WDA0SF/woa05f.pl.

Ogg, J.G., 2004. The Jurassic Period. In: Gradstein, F.M., Ogg, J.G., Smith, A. (Eds.), A Geologic Time Scale 2004. Cambridge Univ. Press, pp. 307-343.

Osete, M.L., Villalaín, J.J., Osete, C., Gialanella, P.R., 2000. Evolución de Iberia durante el Jurásico a partir de datos paleomagnéticos. Geotemas 1, 117-119.

Osete, M.L., Gialanella, P.R., Gómez, J.J., Villalaín, J.J., Goy, A., Heller, F., 2007. Magnetostratigraphy of Early-Middle Toarcian expanded sections from the Iberian Range (central Spain). Earth Planet. Sci. Lett. 259, 319-332.

Osete, M.L., Gómez, J.J., Pavón-Carrasco, F.J., Villalaín, J.J., Palencia, A., Ruiz-Martinez, V. C., Heller, F., 2010. The evolution of Iberia during the Jurassic from palaeomagnetic data. Tectonophysics. doi:10.1016/j.tecto.2010.05.025.

Page, K.N., 2003. The Lower Jurassic of Europe: its subdivision and correlation. Geol. Surv. Denmark Greenland Bull. 1, 23-59.

Pálfy, J., Smith, P.L., 2000. Synchrony between Early Jurassic extinction, oceanic anoxic event, and the Karoo-Ferrar flood basalt volcanism. Geology 28, 747-750.

Poulton, T.P., Callomon, J.H., 1977. A new species of trigoniid bivalve from the Boreal Bathonian (Jurassic) of central East Greenland. Bull. Geol. Soc. Denmark 26, 155-159. Price, G.D., 1999. The $183-210$

evidence of polar ice during the Mesozoic. Earth-Sci. Rev, 48,

uesada, S., Robles, S., Rosales, I., 2005. Depositional architecture and transgressive- regressive cycles within Liassic backstepping carbonate ramps in the Basque- Cantabrian Basin, northern Spain. J. Geol. Soc. Lond. 162, 531-548. 
Rexfort, A., Mutterlose, J., 2009. The role of biogeography and ecology on the isotope signature of cuttlefishes (Cephalopoda, Sepiidae) and the impact on belemnite studies. Palaeogeogr. Palaeoclimatol. Palaeoecol. 284, 153-163.

Richardson, J.R., 1997. Ecology of articulated brachiopods. In: Kaesler, R.L. (Ed.), Treatise on Invertebrate Paleontology. Part H, Brachiopoda (Revised), vol. 1. Geological Society of America \& Paleontological Institute, Boulder, Colorado \& Lawrence, Kansas, pp. 441-462.

Röhl, H.J., Schmid-Röhl, A., Oschmann, W., Frimmel, A., Schwark, L., 2001. The Posidonia Shale (Lower Toarcian) of SW-Germany: an oxygen-depleted ecosystem controlled by sea level and palaeoclimate. Palaeogeogr. Palaeoclimatol. Palaeoecol. 165, 27-52.

Rosales, I., Robles, S., Quesada, S., 2003. Determinación de las variaciones de la temperatura del agua marina en el Lías en la Cuenca Vasco-Cantábrica mediante la utilización de parámetros geoquímicos $\left(\delta^{18} \mathrm{O}, \mathrm{Mg} / \mathrm{Ca}, \mathrm{Sr} / \mathrm{Ca}\right)$. Geogaceta $34,79-82$.

Rosales, I., Quesada, S., Robles, S., 2004. Paleotemperature variations of Early Jurassic seawater recorded in geochemical trends of belemnites from the Basque-Cantabrian basin, northern Spain. Palaeogeogr. Palaeoclimatol. Palaeoecol. 203, 253-275.

Rousselle, L., 1978. Polymorphisme phénotypique et spéciation chez Stolmorhynchia bouchardi (Davidson) s.l. (Brachiopode, Rhynchonellacea) du Toarcien, en Europe et au Magreb. C.R. somm. Soc. Géol. France, 2, pp. 75-78.

Sha, J., 2002. Hispanic Corridor formed as early as Hettangian: on the basis of bivalve fossils. Chin. Sci. Bull. 47, 414-417.

Sælen, G., Doyle, P., Talbot, M.R., 1996. Stable-isotope analyses of belemnite rostra from the Whitby Mudstone Fm., England: surface water conditions during deposition of a marine black shale. Palaios 11, 97-117.

Sælen, G., Tyson, R.V., Telnæs, N., Talbot, M.R., 2000. Contrasting watermass conditions during deposition of the Whitby Mudstone (Lower Jurassic) and Kimmeridge Clay (Upper Jurassic) formations, UK. Palaeogeogr. Palaeoclimatol. Palaeoecol. 163, 163-196.

Schmid-Röhl, A., Röhl, H.J., Oschmann, W., Frimmel, A., Schwark, L., 2002. Palaeoenviron- mental reconstruction of Lower Toarcian epicontinental black shales (Posidonia Shale, SW Germany): global versus regional control. Geobios 35, 13-20.

Smith, P.L., 1983. The Pliensbachian ammonite Dayiceras dayiceroides and Early Jurassic paleogeography. Can. J. Earth Sci. 20, 86-91.

Stampfli, G.M., Borel, G.D., 2004. The TRANSMED transects in space and time: constraints on the paleotectonic evolution of the mediterranean domain. In: Cavazza, W., Roure, F. M., Spakman, W., Stampfli, G.M., Ziegler, P.A. (Eds.), The TRANSMED Atlas - The Mediterraean Region from Crust to Mantle. Springer, Berlin, pp. 53-80 (CD-ROM).

Tchoumatchenco, P.V., 1984. Les zones de brachiopodes du Jurassique d'Algérie du Nord et leur corrélation avec les zones de brachiopodes en Bulgarie. In: Michelsen, O., Zeiss, A. (Eds.), International Symposium on Jurassic Stratigraphy, Erlangen, vol 3, pp. 863-882.

Tremolada, F., van de Schootbrugge, B., Erba, E., 2005. Early Jurassic schizosphaerellid crisis in Cantabria, Spain: implications for calcification rates and phytoplankton evolution across the Toarcian oceanic anoxic event. Paleoceanography 20, PA211. doi:10.1029/2004PA001120.
Twitchett, R.J., 2006. The palaeoclimatology, palaeoecology and palaeoenvironmental analysis of mass extinction events. Palaeogeogr. Palaeoclimatol. Palaeoecol. 232, 190-213.

Twitchett, R.J., Krystyn, L., Baud, A., Wheeley, J.R., Richoz, S., 2004. Rapid marine recovery after the end-Permian mass extinction event in the absence of marine anoxia. Geology 32, 805808.

Valenzuela, M., García-Ramos, J.C., Suárez de Centi, C., 1986. The Jurassic sedimentation in Asturias (N Spain). Trab. Geol. 16, 121-132.

van Breuguel, Y., Baas, M., Schouten, S., Mattioli, E., Sinnighe Damsté, J.S., 2006. Isorenieratane record in black shales from the Paris Basin, France: constrains on recycling of respired $\mathrm{CO} 2$ as a mechanism for negative carbon isotope shifts during the Toarcian oceanic anoxic event. Paleoceanography 21, PA4220. doi:10.1029/2006PA001305.

Vera, J.A., 2001. Evolution of the South Iberian Continental margin. Pery-Tethys Memoir 6: PeriThetyan Rift/ Wrench Basins and Passive Margins: In: Ziegler, P.A., Cavazza, W., Robertson, A.H.F., Crasquin- Soleau, S. (Eds.), Mém. Mus. Natl. Hist. Nat., 186, pp. 109-143.

Vörös, A., 1977. Provinciality of the Mediterranean Lower Jurassic brachiopod fauna: causes and plate tectonic implications. Palaeogeogr. Palaeoclimatol. Palaeoecol. 21, 1-16.

Vörös, A., 1984. Lower and Middle Jurassic brachiopod provinces in the western Tethys. Annales Universitatis Scientiarum Budapestinensis de Rolando Eötvös nominatae, Sectio Geologica, 24 (1982), pp. 207-233.

Vörös, A., 1987. Pliensbachian brachiopod biogeography of the "Mediterranean micro- continent". Acta Geol. Hung. 30, 59-80.

Vörös, A., 2002. Victims of the Early Toarcian anoxic event: the radiation and extinction of Jurassic Koninckinidae (Brachiopoda). Lethaia 35, 345-357.

Vörös, A., 2005. The smooth brachiopods of the Mediterranean Jurassic: refugees or invaders? Palaeogeogr. Palaeoclimatol. Palaeoecol. 223, 222-242.

Walliser, O.H., 1986. Towards a more critical approach to bio-events. Global Bio-Events: A Critical Approach. Proceedings of the First International Meeting of the IGCP Project 216: "Global Biological Events in Earth History": In: Walliser, O.H. (Ed.), Lecture Notes in Earth Sciences, 8, pp. 5-16.

Westermann, G.E.G., 2000. Biochore classification and nomenclature in paleobiogeo- graphy: an attempt at order. Palaeogeogr. Palaeoclimatol. Palaeoecol. 158, 1-13.

Wignall, P.B., Newton, R.J., Little, C.T.S., 2005. The timing of paleoenvironmental change and causeand-effect relationships during the early Jurassic mass extinction in Europe. Am. J. Sci. 305, $1014-1032$

Wright, E.K., 1987. Stratification and paleocirculation of the Late Cretaceous Western Interior Seaway of North America. Geol. Soc. Am. Bull. 99, 480-490.

Zakharov, V.A., Shurygin, B.N., Il'ina, V.I., Nikitenko, B.L., 2006. Pliensbachian-Toarcian biotic turnover in North Siberia and the Artic Region. Stratigr. Geol. Correlation 14, 399-417.

Ziegler, P.A., 1990. Geological Atlas of Western and Central Europe. Shell International Petroleum. Maatschappij B.V. Geological Society Publishing House, Bath, pp. 1-239. 